\title{
Designing an Enhanced Groundwater Sample Collection System
}

\author{
R. Schalla
}

October 1994

Prepared for

the U.S. Department of Energy

under Contract DE-AC06-76RLO 1830

Pacific Northwest Laboratory

Richland, Washington 99352

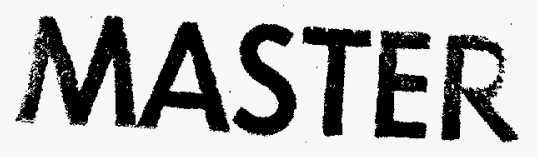

se 



\section{DISCLAIMER}

This report was prepared as an account of work sponsored by an agency of the United States Government. Neither the United States Government nor any agency thereof, nor any of their employees, make any warranty, express or implied, or assumes any legal liability or responsibility for the accuracy, completeness, or usefulness of any information, apparatus, product, or process disciosed, or represents that its use would not infringe privately owned rights. Reference herein to any specific commercial product, process, or service by trade name, trademark, manufacturer, or otherwise does not necessarily constitute or imply its endorsement, recommendation, or favoring by the United States Government or any agency thereof. The views and opinions of authors expressed herein do not necessarily state or reflect those of the United States Government or any agency thereof. 


\section{DISCLAIMER}

Portions of this document may be illegible in electronic image products. Images are produced from the best available original document. 


\section{Executive Summary}

As part of an ongoing technical support mission to achieve excellence and efficiency in environmental restoration activities at the Laboratory for Energy and Health-Related Research (LEHR), the LEHR project manager requested Pacific Northwest Laboratory (PNL) guidance on the design and construction of monitoring wells. The LEHR project, located at the University of California, Davis, also asked PNL to identify the most suitable type of groundwater sampling pump and accessories for their newly constructed monitoring wells. Primarily, the goal was to utilize a monitoring well design that would allow for hydrologic testing and reduce turbidity to minimize the impact of sampling. In the previously installed monitoring wells, the turbidity exceeded regulatory levels for drinking water during the purging cycle and sometimes during the sampling cycle. During the study, purging and sampling procedures were evaluated. Available expertise and American Society for Testing and Materials (ASTM) standards were used as the bases to design, construct, and develop the monitoring wells. Published literature was reviewed to identify the people working in groundwater monitoring who could aid in identifying the most effective sampling pumps to collect representative groundwater samples at LEHR.

The sampling results of the newly designed monitoring wells were clearly superior to those of the previously installed monitoring wells. The new wells exhibited reduced turbidity, in addition to improved access for instrumentation and hydrologic testing. Following the results of the literature review, the variable frequency submersible pump was selected as the best choice between several alternative devices for obtaining groundwater samples. The literature references are listed at the end of this report. Despite some initial difficulties, the actual performance of the variable frequency, submersible pump and its accessories was effective in reducing sampling time and labor costs, and its ease of use was preferred over the previously used bladder pumps. The surface seals system, called the Dedicator, proved to be a useful accessory to prevent surface contamination while providing easy access for water-level measurements and for connecting the pump. Cost savings resulted from the use of the pre-production pumps (beta units) donated by the manufacturer for the demonstration. However, larger savings resulted from shortened field time due to the ease in using the submersible pumps and the surface seal access system. Proper deployment of the monitoring wells also resulted in cost savings and ensured representative samples. 



\section{Glossary}

\begin{tabular}{|c|c|}
\hline $\begin{array}{c}\text { Abbreviation } \\
\text { or } \\
\text { Acronym } \\
\end{array}$ & Definition \\
\hline $\begin{array}{l}\text { ASTM } \\
\text { bgs }\end{array}$ & $\begin{array}{l}\text { American Society for Testing and Materials } \\
\text { below ground surface }\end{array}$ \\
\hline BV & screened interval, sand pack, and casing volume \\
\hline $\mathrm{ft} / \mathrm{ft}$ & foot per foot (slope) \\
\hline gpm & gallons per minute \\
\hline HSU & hydrostratigraphic unit \\
\hline HWL & high water level \\
\hline IC & internal combustion \\
\hline LEHR & Laboratory for Energy and Health-Related Research \\
\hline LWL & low water level \\
\hline MFG & manufacturer \\
\hline MSLD & depth below mean sea level \\
\hline NTU & nephelometric turbidity unit \\
\hline $\mathrm{Pa}$ & a pascal; unit of measure equal to one newton per square meter \\
\hline psi & pound (force) per square inch $\left(\mathrm{lbf} / \mathrm{in}^{2}\right)$ \\
\hline PTFE & polytetrafluoroethylene \\
\hline PVC & polyvinyl chloride \\
\hline SC & screened interval \\
\hline SPSC & screened interval and filter pack \\
\hline SWAT & site wide assessment team \\
\hline TEGD & technical enforcement guidance document \\
\hline TOC & total organic carbon \\
\hline TOH & total organic halogen \\
\hline $\mathrm{UCD}$ & well designation (UC Davis) \\
\hline UC Davis & University of California, Davis \\
\hline VOA & volatile organic analyte \\
\hline VOC & volatile organic constituent \\
\hline
\end{tabular}





\section{Contents}

Executive Summary $\ldots \ldots \ldots \ldots \ldots \ldots \ldots \ldots \ldots \ldots \ldots \ldots \ldots \ldots \ldots \ldots$ iii

Glossary $\ldots \ldots \ldots \ldots \ldots \ldots \ldots \ldots \ldots \ldots \ldots \ldots \ldots \ldots \ldots \ldots \ldots \ldots \ldots \ldots \ldots$

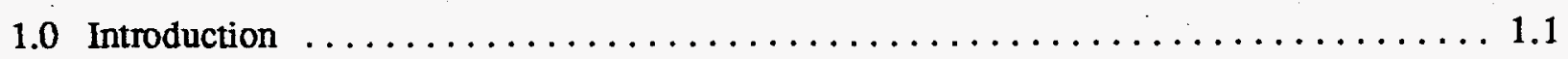

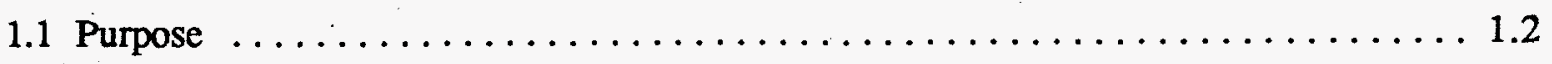

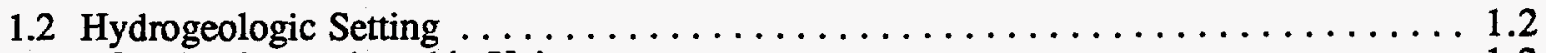

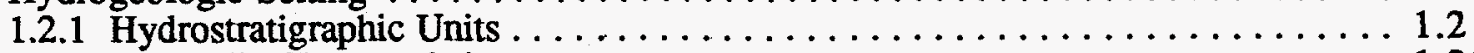

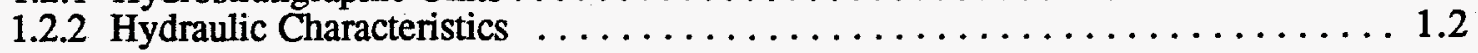

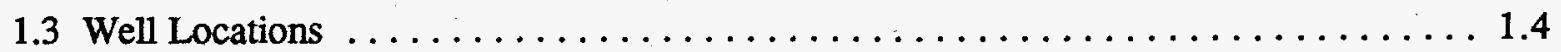

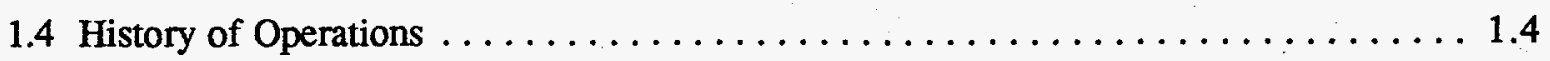

1.5 Contaminants of Concern in Groundwater $\ldots \ldots \ldots \ldots \ldots \ldots \ldots \ldots \ldots \ldots \ldots \ldots$

2.0 Monitoring Well Construction and Development $\ldots \ldots \ldots \ldots \ldots \ldots \ldots \ldots \ldots \ldots$

2.1 Basis for Improved Well Design $\ldots \ldots \ldots \ldots \ldots \ldots \ldots \ldots \ldots \ldots \ldots \ldots \ldots \ldots \ldots \ldots$

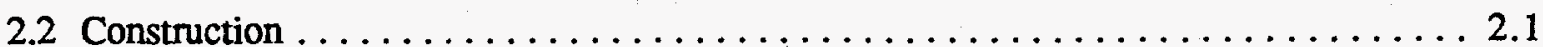

2.2.1 Well Screen and Filter Pack Design $\ldots \ldots \ldots \ldots \ldots \ldots \ldots \ldots \ldots \ldots \ldots \ldots \ldots \ldots \ldots \ldots$

2.2.2 Material/Contaminant Compatibility $\ldots \ldots \ldots \ldots \ldots \ldots \ldots \ldots \ldots \ldots \ldots \ldots \ldots \ldots \ldots \ldots \ldots .2 .2$

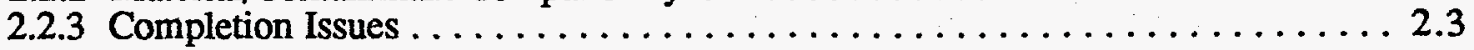

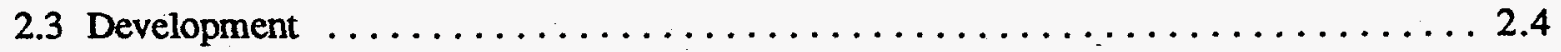

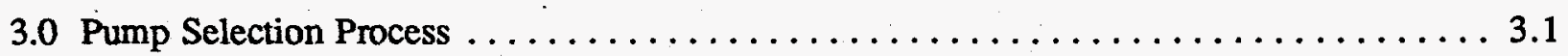

3.1 Sampling Process Considerations $\ldots \ldots \ldots \ldots \ldots \ldots \ldots \ldots \ldots \ldots \ldots \ldots \ldots \ldots \ldots \ldots \ldots \ldots$

3.2 Categories of Sample Collection Devices $\ldots \ldots \ldots \ldots \ldots \ldots \ldots \ldots \ldots \ldots \ldots$

3.3 Pump Performance Criteria $\ldots \ldots \ldots \ldots \ldots \ldots \ldots \ldots \ldots \ldots \ldots \ldots \ldots \ldots \ldots \ldots \ldots \ldots \ldots \ldots .2$

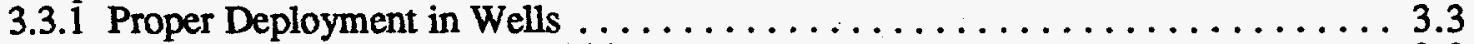

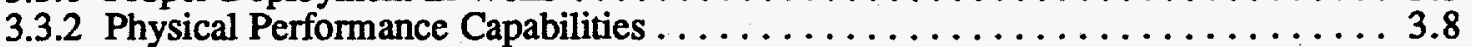

3.3.3 Capability of Obtaining a Representative Sample $\ldots \ldots \ldots \ldots \ldots \ldots \ldots \ldots .8$

3.3.4 Pump Efficiency . . . . . . . . . . . . . . . . . . . . . . . . 3.9

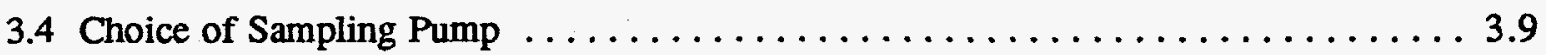

4.0 Performance of Monitoring Wells, Pumps, and Accessories $\ldots \ldots \ldots \ldots \ldots \ldots \ldots .1$

4.1 Monitoring Well Performance $\ldots \ldots \ldots \ldots \ldots \ldots \ldots \ldots \ldots \ldots \ldots \ldots \ldots \ldots \ldots .1$

4.2 Performance of Submersible Pump and Accessories $\ldots \ldots \ldots \ldots \ldots \ldots \ldots .2$ 


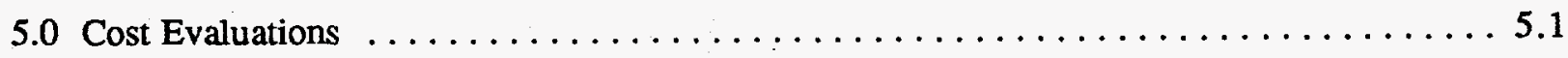

5.1 Monitoring Well Costs $\ldots \ldots \ldots \ldots \ldots \ldots \ldots \ldots \ldots \ldots \ldots \ldots \ldots \ldots \ldots \ldots \ldots \ldots \ldots$

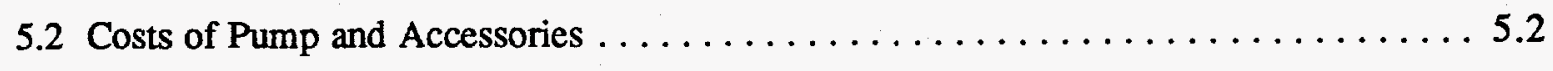

6.0 Summary and Conclusions $\ldots \ldots \ldots \ldots \ldots \ldots \ldots \ldots \ldots \ldots \ldots \ldots \ldots \ldots \ldots \ldots \ldots \ldots \ldots \ldots$

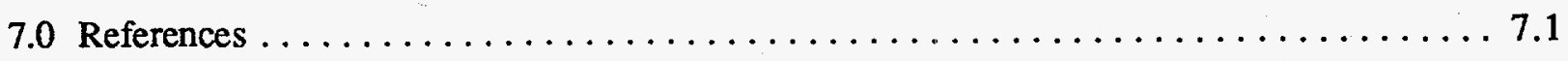




\section{Figures}

1.1 Generalized Cross Section of First and Second Hydrostratigraphic Units $\ldots \ldots \ldots \ldots$

1.2 Monitoring Well Location Map at LEHR $\ldots \ldots \ldots \ldots \ldots \ldots \ldots \ldots \ldots \ldots \ldots \ldots \ldots \ldots \ldots \ldots \ldots$

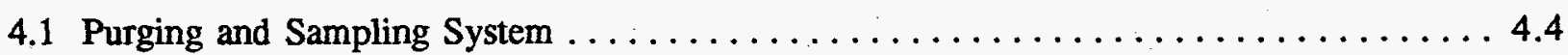

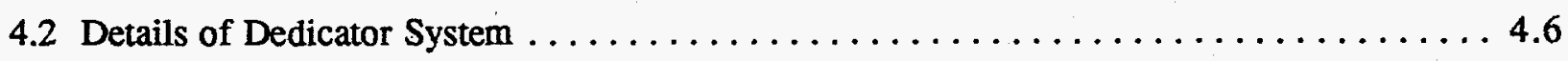

\section{Tables}

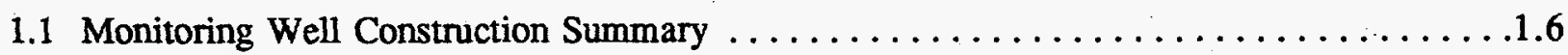

1.2 Contaminants of Concem and Constituents of Interest $\ldots \ldots \ldots \ldots \ldots \ldots \ldots$

3.1 Operational Characteristics of Purging and Sampling Devices $\ldots \ldots \ldots \ldots \ldots \ldots$

4.1 Well Construction Information and Pump Depths at LEHR $\ldots \ldots \ldots \ldots \ldots \ldots \ldots$

5.1 Cost Comparison of Screen Alternatives in 10-Cm (4-In.) Diameter Wells . . . . . . 5.1

5.2 Comparison of Three Variable Discharge Pumps $\ldots \ldots \ldots \ldots \ldots \ldots \ldots \ldots \ldots \ldots \ldots$ 


\subsection{Introduction}

As part of an ongoing technical support mission to achieve excellence and efficiency in environmental restoration activities at the Laboratory for Energy and Health-Related Research (LEHR), the LEHR project manager requested Pacific Northwest Laboratory (PNL)(a) guidance on the design and construction of monitoring wells. The project manager also requested identification of the most suitable type of groundwater sampling pump and accessories for the newly constructed monitoring wells at LEHR.

This report includes a brief description of the hydrogeologic setting and wells used for this particular demonstration of enhanced groundwater sample collection systems. Some discussion is also provided regarding regulatory requirements and guidance, and contaminants of concern at LEHR. The report focuses primarily on the groundwater sample collection system which includes: the monitoring well, the sampling pump, and its accessory components. Included are descriptions of the construction and development of the monitoring wells and the resulting benefits, the performance criteria used to select the pump and accessories, and the actual performance of the enhancements of the groundwater collection system at 10 new wells. Conclusions are based on the literature review and the reference list in Section 7.0.

Radiological and chemical constituents are monitored in the groundwater at LEHR. The current missions of LEHR decommissioning, which include waste management and environmental restoration, as well as compliance with environmental regulations concerned with groundwater, require collection of reliable groundwater samples. To achieve this goal, an effective groundwater sample collection system was designed, constructed, and installed during the years 1990 through 1992.

This report contains seven sections. Section 2.0 describes the processes for constructing and developing monitoring wells. Section 3.0 explains the method for pump selection. Section 4.0 discusses the actual performance of the equipment. Section 5.0 includes details of various cost savings. Section 6.0 provides a concluding paragraph about the improvements of the groundwater collection system at the University of California, Davis (UC Davis). Section 7.0 lists the sources used as reference material for this report.

(a) Pacific Northwest Laboratory is operated for the U.S. Department of Energy by Battelle Memorial Institute under Contract DE-AC06-76RLO 1830. 


\subsection{Purpose}

The purpose of this report is to present the results of the design, installation, and actual operation of the enhanced groundwater sample collection system at LEHR. The information presents the rationale used for the sample collection system improvements and delineates cost savings. Based on knowledge of the LEHR site, the groundwater was considered to contain contaminants of concern in solution in the aqueous phase.

\subsection{Hydrogeologic Setting}

The two most shallow hydrostratigraphic units (HSU-1 and HSU-2) and their hydraulic characteristics comprise the hydrogeologic setting of interest at the time the first 24 monitoring wells were installed. Descriptions of these units are provided in the following subsections.

\subsubsection{Hydrostratigraphic Units}

At the time of this effort, the focus was on the most likely contaminant transport pathways, the uppermost aquifers at the site. During this investigation, the focus was on two shallow hydrostratigraphic units. The shallowest, HSU-1, extends from 3 to $24 \mathrm{~m} \mathrm{(10} \mathrm{to} 80 \mathrm{ft}$ ) bgs, and consists of very fine-grained sandy silt or silty sand to sandy clay. Located within $1.6 \mathrm{~km}(1 \mathrm{mi})$ of the site, the second unit, HSU-2, consists of coarse sand and gravel, and is relatively extensive. The HSU-2 unit is found between 24 and $41 \mathrm{~m}$ (80 and $135 \mathrm{ft}$ ) bgs. Because groundwater depths range from approximately 14 to $21 \mathrm{~m}$ (45 to $70 \mathrm{ft}$ ) bgs, HSU-1 is generally thought of as unconfined and the deeper HSU-2 layer is generally thought of as confined. Actually, the two units are hydraulically interconnected and the amount of isolation is minor. The character of these units not only affects the contaminant residence and travel times, but also can impact the sample collection system. Below HSU-2 is a lower clay zone that is several meters thick. Figure 1.1 is a generalized cross section of the LEHR site that indicates the high water level (HWL) and low water level (LWL) of two UCD wells.

\subsubsection{Hydraulic Characteristics}

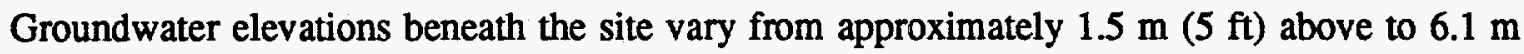
$(20 \mathrm{ft})$ below mean sea level throughout the year. Generally, water levels are at their highest level in early spring and at their lowest in late summer. Lateral groundwater gradients in HSU-1 vary from 0.0001 to $0.0015 \mathrm{ft} / \mathrm{ft}$, and are typically $0.0015 \mathrm{ft} / \mathrm{ft}$ in HSU-2. Generally, groundwater flow direction 


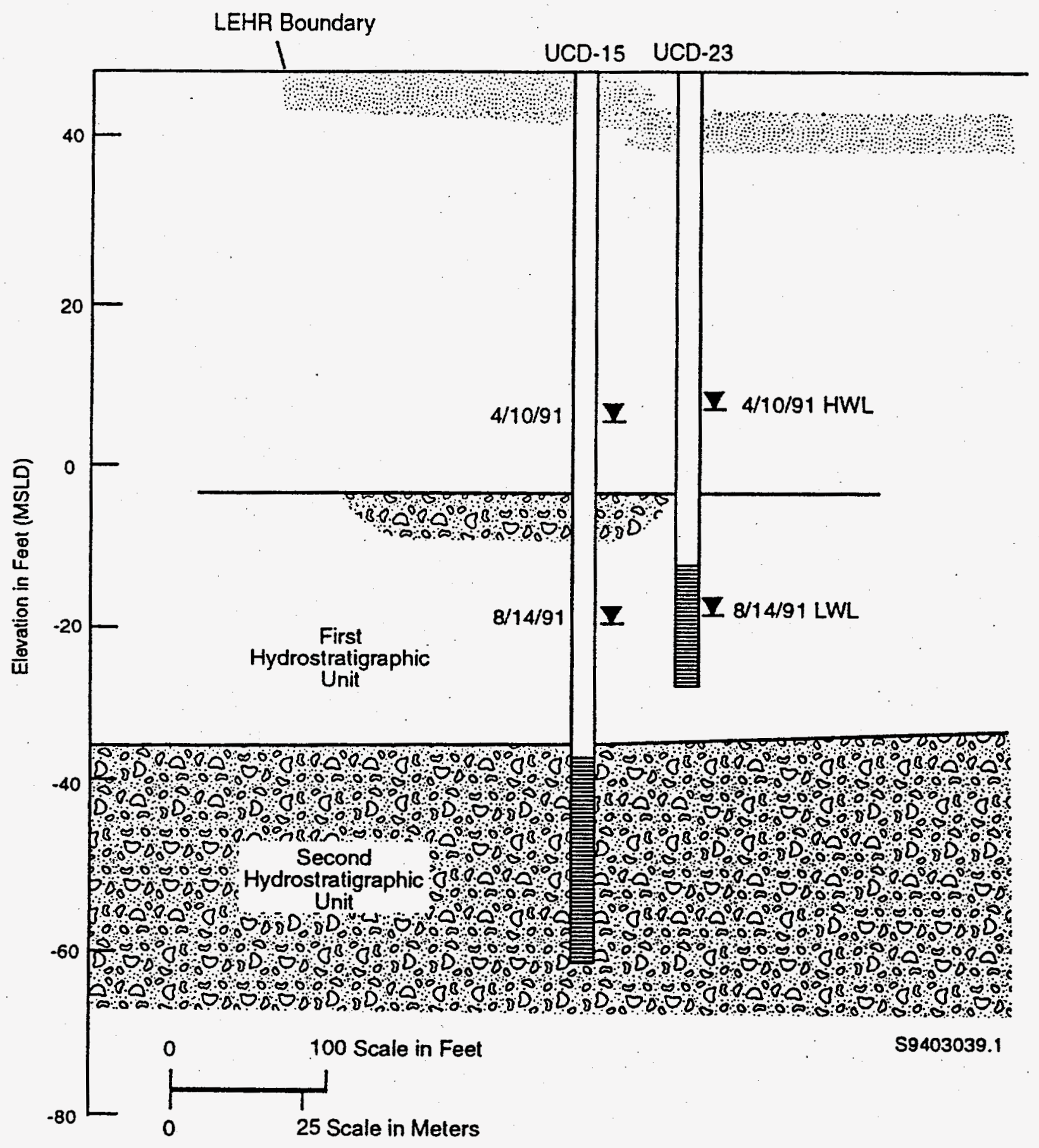

Figure 1.1. Generalized Cross Section of First and Second Hydrostratigraphic Units 
is toward the northeast, but temporary local changes in flow direction occur, particularly in HSU-1. Putah Creek (see Figure 1.2) recharges locally and creates a groundwater flow barrier in HSU-1. Horizontal hydraulic conductivities average $1.5 \times 10^{-3} \mathrm{~cm} / \mathrm{sec}\left(4.9 \times 10^{-5} \mathrm{ft} / \mathrm{sec}\right)$ for HSU-1 and $9.0 \times 10^{-3} \mathrm{~cm} / \mathrm{sec}\left(3.0 \times 10^{-4} \mathrm{ft} / \mathrm{sec}\right)$ for HSU-2.

\subsection{Well Locations}

During the site investigation, 10 monitoring wells were constructed. Wells UCD-18 through UCD-24 were screened in the finer-grained silt-rich sand of the HSU-1 unit and three others, UCD-15 through UCD-17, were screened in the deeper, coarser-grained sequence of sand and gravel of HSU-2. Table 1.1 provides a summary of monitoring wells, including the 10 constructed most recently. The locations of the wells, in relation to the site, are shown in Figure 1.2.

\subsection{History of Operations}

During the 30-yr operation of the LEHR facility, a variety of wastes were generated and disposed of on-site. These wastes included radioactive, biological, chemical, municipal, and laboratory debris. A brief summary of waste generating processes and potential sources of environmental impacts on groundwater at the LEHR facility are presented in the following paragraphs.

UC Davis has conducted radiological studies on laboratory animals for the U.S. Department of Energy (DOE) since the 1950s. The initial studies, conducted for the U.S. Atomic Energy Commission (AEC, now DOE), involved the irradiation of beagles at the UC Davis main campus. Full-scale experimental use of radioactive materials, including strontium-90 and radium-226, began at LEHR in 1960. Disposal locations at the LEHR facility included the two disposal units of the UC Davis campus landfill. Disposal Unit No. 1 was used during the 1940s and 1950s. Disposal Unit No. 2 was used from 1956 to 1967. A third landfill disposal unit was used by LEHR from 1963 to 1967. The combined total acreage of the three landfills was approximately 2.4 ha (6 a).

Radiologic wastes generated from animal experiments using bone-seeking radionuclides were treated using two primary systems. From 1960 to 1987, effluent from strontium-90 experiments was processed through an Imhoff sewage treatment system. From 1982 to 1984 , a total of $39.59 \mu \mathrm{Ci}$ of plutonium-241 and $0.136 \mu \mathrm{Ci}$ of americium-241 were processed through the Imhoff treatment 


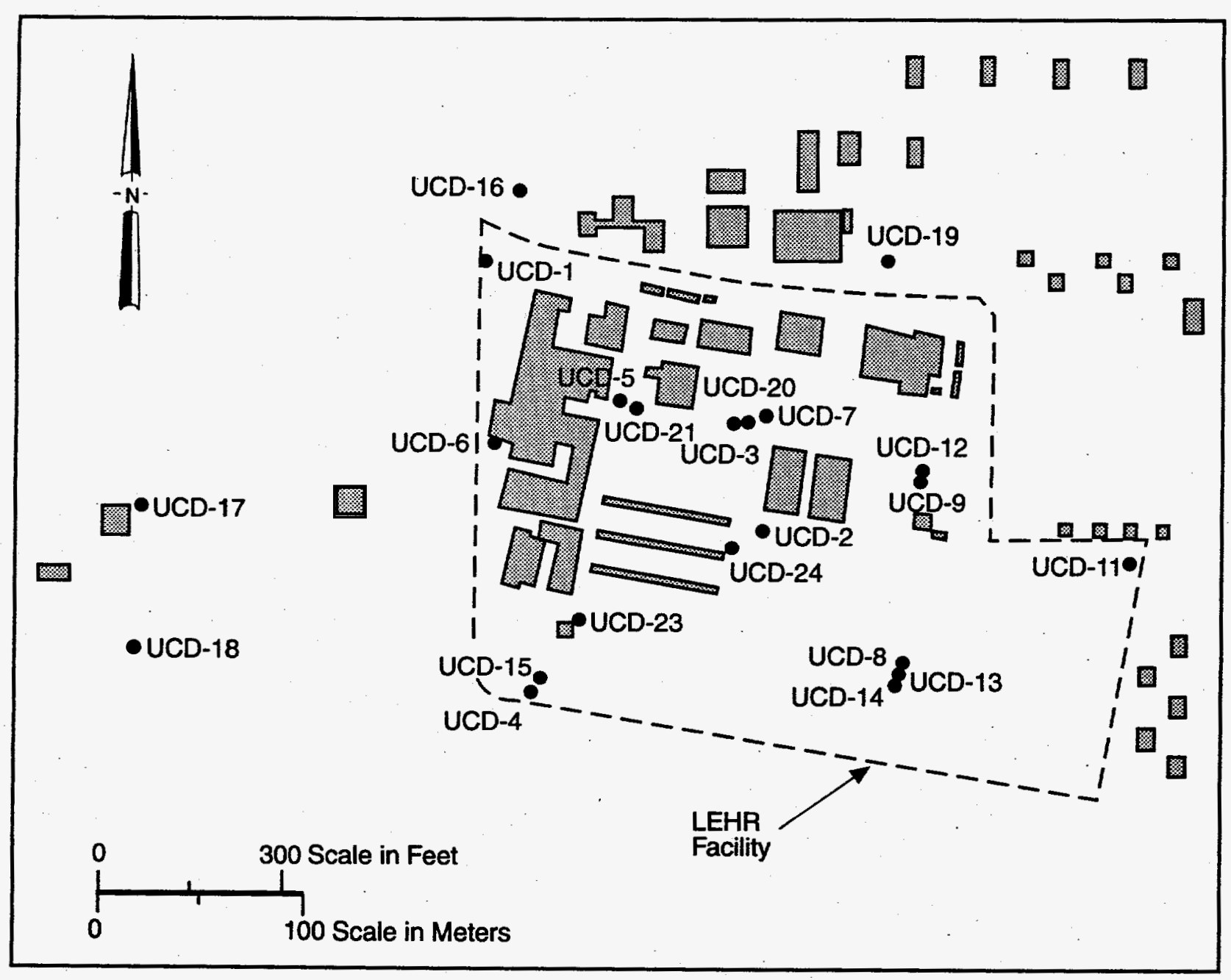

S9403039.2

Figure 1.2. Monitoring Well Location Map at LEHR

system. This system uses a series of settling tanks and cation exchange columns to treat approximately 758 to $1895 \mathrm{~L}$ (200 to $500 \mathrm{gal}$ ) per day of waste, prior to discharge to leach fields. The total throughput of strontium-90 to the Imhoff system is estimated at $943.2 \mathrm{mCi}$. After treatment through the Imhoff system, an estimated $2.55 \mathrm{mCi}$ of strontium-90 were released to the Imhoff leach field and subsurface soil. The half-life of strontium- 90 is $29 \mathrm{yr}$. 
Table 1.1. Monitoring Well Construction Summary

UCD-1 Through UCD-6

\begin{tabular}{|c|c|c|c|c|c|c|}
\hline & UCD-1 & UCD-2* & UCD-3 & UCD-4 & UCD-5 & $\mathrm{UCD}-6$ \\
\hline $\begin{array}{l}\text { Casing Typel } \\
\text { Diameter }\end{array}$ & $\begin{array}{l}\text { PVC/5.1 cm } \\
\text { (2 in.) }\end{array}$ & & $\begin{array}{l}\text { PVC/5.1 cm } \\
\text { ( } 2 \text { in.) }\end{array}$ & $\begin{array}{l}\text { PVC/S.1 cm } \\
\text { ( } 2 \text { in.) }\end{array}$ & $\begin{array}{l}\text { PVC/S.1 cm } \\
\text { (2 in) }\end{array}$ & $\begin{array}{l}\text { PVC/5.1 cm } \\
\text { (2 in.) }\end{array}$ \\
\hline $\begin{array}{l}\text { Screen Typel } \\
\text { Slo Size }\end{array}$ & $\begin{array}{l}\text { PVC } 051 \mathrm{~mm} \\
(0.020 \mathrm{in})\end{array}$ & & $\begin{array}{l}\text { PYCO.51 mm } \\
\text { (0.020 in.) }\end{array}$ & $\begin{array}{l}\text { PVC } 0.51 \mathrm{~mm} \\
(0.020 \mathrm{in} .)\end{array}$ & $\begin{array}{l}\text { PVC0 } 51 \mathrm{~mm} \\
(0.020 \mathrm{in})\end{array}$ & $\begin{array}{l}\text { PVCOS1 mm } \\
\text { (0.020 in) }\end{array}$ \\
\hline Slot Type & Slocted & & Slouted & Slocted & Slotied & Slotted \\
\hline Screen Length & $3.1 \mathrm{~m}(10 \mathrm{ft})$ & & $3.1 \mathrm{~m}(10 \mathrm{ft})$ & $3.1 \mathrm{~m}(10 \mathrm{ft})$ & $3.1 \mathrm{~m}(10 \mathrm{f})$ & $3.1 \mathrm{~m}(10 \mathrm{ft})$ \\
\hline $\begin{array}{l}\text { Sereen Interval } \\
\text { bgt }\end{array}$ & $\begin{array}{c}14.7-17.2 \mathrm{~m} \\
(46.5-56.5 \mathrm{ft})\end{array}$ & & $\begin{array}{l}11.9-14.9 \mathrm{~m} \\
(39.0-49.0 \mathrm{ft})\end{array}$ & $\begin{array}{c}13.7-16.8 \mathrm{~m} \\
(45.0-55.0 \mathrm{f})\end{array}$ & $\begin{array}{c}11.6-14.6 \mathrm{~m} \\
(38.0-48.0 \mathrm{ft})\end{array}$ & $\begin{array}{c}12.2-15.2 \mathrm{~m} \\
(40.0-50.0 \mathrm{f})\end{array}$ \\
\hline Silt Trap & No & & No & No & No & No \\
\hline Filler Pack Type & Lone Star & & Lone Star & Lone Star & Lone Star & Lone Sur \\
\hline Mesh Sieve Size & $8-20$ & & $8-20$ & $8-20$ & $8 \cdot 20$ & $8 \cdot 20$ \\
\hline Filter Pack Interval & $\begin{array}{c}14.6-17.2 \mathrm{~m} \\
(48.0-56.5 \mathrm{ft})\end{array}$ & & $\begin{array}{c}10.4-15.7 \mathrm{~m} \\
(34.0-51.5 \mathrm{ft})\end{array}$ & $\begin{array}{l}122-16.8 \mathrm{~m} \\
(40.0-55.0 \mathrm{ft})\end{array}$ & $\begin{array}{c}10.1-14.6 \mathrm{~m} \\
(33.0-48.0 \mathrm{ft})\end{array}$ & $\begin{array}{l}.10 .7-15.2 \mathrm{~m} \\
(35.0-50.0 \mathrm{ft})\end{array}$ \\
\hline Primary Seal & Grout & 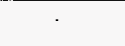 & Grout & Grout & Grout & Grout \\
\hline Secondary Seal & Bentonite & & Bentonite & Bentonite & Bentonite & Bentonite \\
\hline Surface Completion & Aboveground & & Aboveground & Aboveground & Aboveground & Belowground \\
\hline Purmp Type & Redi-Flo2 & & Bladder & Redi-Flo2 & Bladder & Bladder \\
\hline $\begin{array}{l}\text { HSU Unit and } \\
\text { Depth of Casing }\end{array}$ & $\begin{array}{l}1 s / 17.2 \mathrm{~m} \\
(56.5 \mathrm{ft})\end{array}$ & & $\begin{array}{l}1 \mathrm{st} / 14.9 \mathrm{~m} \\
(49.0 \mathrm{f})\end{array}$ & $\begin{array}{l}1 \mathrm{~s} / 16.8 \mathrm{~m} \\
(55.0 \mathrm{ft})\end{array}$ & $\begin{array}{l}1 \mathrm{st} / 14.6 \mathrm{~m} \\
(48.0 \mathrm{f})\end{array}$ & $\begin{array}{l}1 \mathrm{~s} / 15.2 \mathrm{~m} \\
(50.0 \mathrm{ft})\end{array}$ \\
\hline Date Completed & $10 / 09 / 87$ & & $10 / 23 / 87$ & $10 / 14 / 87$ & $10 / 22 / 87$ & $10 / 21 / 87$ \\
\hline
\end{tabular}

*Abendoned well

UCD-7 Through UCD-12

\begin{tabular}{|c|c|c|c|c|c|c|}
\hline & UCD-7 & $\mathrm{UCD}-8$ & UCD-9 & UCD-10 & UCD-11 & UCD-12 \\
\hline $\begin{array}{l}\text { Casing Typel } \\
\text { Diumeter }\end{array}$ & $\begin{array}{l}\text { PVC/5.1 cm } \\
\text { (2 in.) }\end{array}$ & $\begin{array}{l}\text { PVC/S.1 cm } \\
\text { (2 in) }\end{array}$ & $\begin{array}{l}\text { PVC/5.1 cm } \\
\text { (2 in.) }\end{array}$ & $\begin{array}{l}\text { PVC } 10.2 \mathrm{~cm} \\
(4 \text { in. })\end{array}$ & $\begin{array}{l}\text { PVC } / 10.2 \mathrm{~cm} \\
\text { (4 in.) }\end{array}$ & $\begin{array}{l}\text { PVC/10.2 } \mathrm{cm} \\
\text { (4 in.) }\end{array}$ \\
\hline $\begin{array}{l}\text { Screen Typel } \\
\text { Sla Size }\end{array}$ & $\begin{array}{l}\text { PVC0.51 mm } \\
(0.020 \mathrm{in})\end{array}$ & $\begin{array}{l}\text { PVCDS1 mm } \\
(0.020 \mathrm{in})\end{array}$ & $\begin{array}{l}\text { PVCD.51 mm } \\
\text { (0.020 in.) }\end{array}$ & $\begin{array}{l}\text { PVC0 } 025 \mathrm{~mm} \\
(0.010 \mathrm{in})\end{array}$ & $\begin{array}{l}\text { PVC } 0.25 \mathrm{~mm} \\
(0.010 \mathrm{in})\end{array}$ & $\begin{array}{l}\text { PVCD.25 mm } \\
(0.010 \text { in. })\end{array}$ \\
\hline Slat Type & Sloued & Sloned & Sloued & Slotted & Sloced & Sloued \\
\hline Screen Lengh & $3.1 \mathrm{~m}(10 \mathrm{ft})$ & $3.1 \mathrm{~m}(10 \mathrm{ft})$ & $3.1 \mathrm{~m}(10 \mathrm{ft})$ & $4.6 m(15 f)$ & $4.6 \mathrm{~m}(15 \mathrm{fr})$ & $4.6 m(15 f)$ \\
\hline $\begin{array}{l}\text { Screen Interval } \\
\text { bgs }\end{array}$ & $\begin{array}{l}24.4-27.4 \mathrm{~m} \\
(80.0-90.0 \mathrm{ft})\end{array}$ & $\begin{array}{c}13.3-16.3 \mathrm{~m} \\
(43.5-53.5 \mathrm{ft})\end{array}$ & $\begin{array}{c}12.2-15.2 \mathrm{~m} \\
(40.0 \cdot 50.0 \mathrm{ft})\end{array}$ & $\begin{array}{c}16.5-21.0 \mathrm{~m} \\
(54.0-69.0 \mathrm{ft})\end{array}$ & $\begin{array}{c}15.2-19.8 \mathrm{~m} \\
(50.0-65.0 \mathrm{ft})\end{array}$ & $\begin{array}{c}15.1-19.7 \mathrm{~m} \\
(49.5-64.5 \mathrm{ft})\end{array}$ \\
\hline Silt Trap & No & No & No & Yes & Yes & Yes \\
\hline Filier Pack Type & Lone Star & Lone Star & Lone Star & Lone Star & Lone Star & Lone Star \\
\hline Mesh Sieve Size & $8-20$ & $8-20$ & $8-20$ & $16-40$ & $16-40$ & $16-40$ \\
\hline Filter Pack Interval & $\begin{array}{c}22.9-27.4 \mathrm{~m} \\
(75.0-90.0 \mathrm{ft})\end{array}$ & $\begin{array}{c}11.9-16.3 \mathrm{~m} \\
(39.0-53.5 \mathrm{ft})\end{array}$ & $\begin{array}{l}10.8-15.2 \mathrm{~m} \\
(35.0-50.0 \mathrm{ft})\end{array}$ & $\begin{array}{c}15.9-21.3 \mathrm{~m} \\
(52.0-70.0 \mathrm{ft})\end{array}$ & $\begin{array}{c}17.4-20.3 \mathrm{~m} \\
(57.0-66.5 \mathrm{ft})\end{array}$ & $\begin{array}{c}14.3-20.3 \mathrm{~m} \\
(47.0-66.5 \mathrm{f})\end{array}$ \\
\hline Primary Seal & Grout & Grout & Grout & Grout & Grout & Grout \\
\hline Secondary Seal & Bentonite & Bentonite & Bentonite & Bentonite & Bentonite & Bentonite \\
\hline Surface Completion & Aboveground & Aboveground & Aboveground & Aboveground & Aboveground & Aboveground \\
\hline Pump Type & Redi-Flo2 & Bladder & Bladder & Redi-Flo2 & Redi-Flo2 & Redi-Flo2 \\
\hline $\begin{array}{l}\text { HSU Unit and } \\
\text { Depth of Casing }\end{array}$ & $\begin{array}{c}2 \mathrm{nd} / 27.4 \mathrm{~m} \\
(90.0 \mathrm{ft})\end{array}$ & $\begin{array}{c}1 \mathrm{st} / 16.3 \mathrm{~m} \\
(53.5 \mathrm{ft})\end{array}$ & $\begin{array}{c}1 \mathrm{st} / 15.2 \mathrm{~m} \\
(50.0 \mathrm{ft})\end{array}$ & $\begin{array}{l}1 \mathrm{st} / 213 \mathrm{~m} \\
(70.0 \mathrm{fi})\end{array}$ & $\begin{array}{c}1,120.3 \mathrm{~m} \\
(66.5 \mathrm{f})\end{array}$ & $\begin{array}{c}1 \mathrm{st} / 20.3 \mathrm{~m} \\
(66.5 \mathrm{ft})\end{array}$ \\
\hline Date Completed & $11 / 05 / 87$ & $11 / 03 / 87$ & $11 / 04 / 87$ & $10 / 11 / 89$ & $10 / 17 / 89$ & $10 / 19 / 89$ \\
\hline
\end{tabular}


Table 1.1. (contd)

UCD-13 Through UCD-18

\begin{tabular}{|c|c|c|c|c|c|c|}
\hline & UCD-13 & UCD-14 & UCD-15 & UCD-16 & UCD-17 & UCD-18. \\
\hline $\begin{array}{l}\text { Casing Type/ } \\
\text { Dimmeler }\end{array}$ & $\begin{array}{l}\mathrm{PVC} / 10.2 \mathrm{~cm} \\
\text { (4 in.) }\end{array}$ & $\begin{array}{l}\text { PVC } / 10.2 \mathrm{~cm} \\
\text { (4 in.) }\end{array}$ & $\begin{array}{l}\text { PVC } / 10.2 \mathrm{~cm} \\
\text { (4 in) }\end{array}$ & $\begin{array}{l}\text { PVC } / 10.2 \mathrm{~cm} \\
(4 \mathrm{in} .)\end{array}$ & $\begin{array}{l}\mathrm{PVC} / 10.2 \mathrm{~cm} \\
(4 \mathrm{in} .)\end{array}$ & $\begin{array}{l}\text { PVC } / 10.2 \mathrm{~cm} \\
\text { (4 in.) }\end{array}$ \\
\hline $\begin{array}{l}\text { Screen Typel } \\
\text { Slo Size }\end{array}$ & $\begin{array}{l}\text { PVC0.25 mm } \\
(0.010 \mathrm{in} .)\end{array}$ & $\begin{array}{l}\text { PVC } 0.51 \mathrm{~mm} \\
(0.020 \mathrm{in} .)\end{array}$ & $\begin{array}{l}5 S 0.51 \mathrm{~mm} \\
(0.020 \mathrm{in} .)\end{array}$ & $\begin{array}{l}S S / 0.76 \mathrm{~mm} \\
(0.030 \mathrm{in} .)\end{array}$ & $\begin{array}{l}S 5 / 0.51 \mathrm{~mm} \\
(0.020 \mathrm{in} .)\end{array}$ & $\begin{array}{l}550.25 \mathrm{~mm} \\
(0.010 \mathrm{in} .)\end{array}$ \\
\hline Slat Type & Sloned & Sloned & Wirewrap & Wirewrap & Wirewrap & Wirewrap \\
\hline Screen Length & $4.6 \mathrm{~m}(15 \mathrm{ft})$ & $3.1 \mathrm{~m}(10 \mathrm{f})$ & $7.6 \mathrm{~m}(25 \mathrm{f})$ & $7.6 \mathrm{~m}(25 \mathrm{f})$ & $7.6 \mathrm{~m}(25 \mathrm{fi})$ & $4.6 \mathrm{~m}(15 \mathrm{ft})$ \\
\hline $\begin{array}{l}\text { Screen Interval } \\
\text { bgs }\end{array}$ & $\begin{array}{c}15.2-19.8 \mathrm{~m} \\
(50.0-65.0 \mathrm{ft})\end{array}$ & $\begin{array}{l}22.9-25.9 \mathrm{~m} \\
(75.0-85.0 \mathrm{ft})\end{array}$ & $\begin{array}{c}27.7-35.4 \mathrm{~m} \\
(91.0-116.0 \mathrm{ft})\end{array}$ & $\begin{array}{c}27.9-35.5 \mathrm{~m} \\
(91.5-116.5 \mathrm{ft})\end{array}$ & $\begin{array}{c}26.8-34.4 \mathrm{~m} \\
(88.0-113.0 \mathrm{ft})\end{array}$ & $\begin{array}{c}17.0-21.6 \mathrm{~m} \\
(55.9-70.9 \mathrm{ft})\end{array}$ \\
\hline Silt Trap & Yes & No & No & No & No & No \\
\hline Filter Pack Type & Lone Star & Lone Star & Lone Sur & Lone Star & Lone Star & Lone Star \\
\hline Mesh Sieve Size & $16-40$ & $16-40$ & $12 \cdot 20$ & $12 \cdot 20$ & $12 \cdot 20$ & $16-40$ \\
\hline Filier Pack Interval & $\begin{array}{c}14.3-20.6 \mathrm{~m} \\
(47.0-67.5 \mathrm{ft})\end{array}$ & $\begin{array}{c}21.0-26.2 \mathrm{~m} \\
(69.0-86.0 \mathrm{ft})\end{array}$ & $\begin{array}{c}26.2-36.7 \mathrm{~m} \\
(86.0-120.5 \mathrm{ft})\end{array}$ & $\begin{array}{c}27.1-37.2 \mathrm{~m} \\
(89.0-122.0 \mathrm{ft})\end{array}$ & $\begin{array}{c}25.6-34.4 \mathrm{~m} \\
(84.0-113.0 \mathrm{ft})\end{array}$ & $\begin{array}{c}15.5-21.2 \mathrm{~m} \\
(51.0-69.5 \mathrm{f})\end{array}$ \\
\hline Primary Seal & Grout & Grout & Grout & Grout & Grout & Grout \\
\hline $\begin{array}{l}\text { Secondary Seal } \\
\text { Thickness }\end{array}$ & Bentonite & Beatonite & $\begin{array}{c}\text { Bentonite } \\
6.4 \mathrm{~m}(21, \mathrm{fl}) \\
N_{\alpha}\end{array}$ & $\begin{array}{c}\text { Bentonite } \\
5.5 \mathrm{~m}(18, \mathrm{ft}) \\
.0\end{array}$ & $\begin{array}{c}30-50 \text { Mesh Sand } \\
0.9 \mathrm{~m}(3.0 \mathrm{ft}) \\
\text { Volclay } \\
0.9 \mathrm{~m}(3.0 \mathrm{ft})\end{array}$ & Bentonite \\
\hline Surface Completion & Aboveground & Aboveground & Aboveground & Aboveground & Aboveground & Aboveground \\
\hline Pump Type & Redi-Flo2 & Redi-Flo2 & Redi-Flo2 & Redi-Flo2 & Redi-Flo2 & Redi-Flo2 \\
\hline $\begin{array}{l}\text { HSU Unit and } \\
\text { Depth of Casing }\end{array}$ & $\begin{array}{l}152 \sqrt{20.3 \mathrm{~m}} \\
(66.5 \mathrm{ft})\end{array}$ & $\begin{array}{c}2 \mathrm{nd} / 25.9 \mathrm{~m} \\
(85.0 \mathrm{ft})\end{array}$ & $\begin{array}{c}2 \mathrm{nd} / 35.4 \mathrm{~m} \\
(116.0 \mathrm{ft})\end{array}$ & $\begin{array}{c}2 \mathrm{nd} / 35.5 \mathrm{~m} \\
(116.5 \mathrm{ft})\end{array}$ & $\begin{array}{c}2 \mathrm{nd} / 34.4 \mathrm{~m} \\
(113.0 \mathrm{ff})\end{array}$ & $\begin{array}{c}1 \mathrm{st} / 21.6 \mathrm{~m} \\
(70.9 \mathrm{ft})\end{array}$ \\
\hline Date Completed & $10 / 26 / 89$ & $11 / 15 / 89$ & $03 / 28 / 90$ & $04 / 04 / 90$ & $0,4 / 10 / 90$ & $10 / 04 / 90$ \\
\hline
\end{tabular}

UCD-19 Through UCD-24

\begin{tabular}{|c|c|c|c|c|c|c|}
\hline & UCD-19 & UCD-20 & UCD-21 & UCD-22 & UCD-23 & UCD-24 \\
\hline $\begin{array}{l}\text { Cesing Typel } \\
\text { Diameter }\end{array}$ & $\begin{array}{c}\mathrm{PVC} / 10.2 \mathrm{~cm} \\
\text { (4 in.) }\end{array}$ & $\begin{array}{l}\text { PVC/10.2 cm } \\
\text { (4 in.) }\end{array}$ & $\begin{array}{c}\text { PVC/10.2 cm } \\
(4 \text { in })\end{array}$ & $\begin{array}{c}\text { PVC/10.2 } \\
(4 \text { in. })\end{array}$ & $\begin{array}{c}\text { PVC/10.2 } \\
(4 \mathrm{in})\end{array}$ & $\begin{array}{l}\text { PVC } 110.2 \mathrm{~cm} \\
\text { (4 in.) }\end{array}$ \\
\hline $\begin{array}{l}\text { Screen Typel } \\
\text { Sla Size }\end{array}$ & $\begin{array}{l}S S .0 .25 \mathrm{~mm} \\
(0.010 \mathrm{in})\end{array}$ & $\begin{array}{l}\text { SS/0.25 mm } \\
(0.010 \mathrm{in} .)\end{array}$ & $\begin{array}{l}S 5.51 \mathrm{~mm} \\
(0.020 \mathrm{in} .)\end{array}$ & $\begin{array}{c}5 S / 0.25 \mathrm{~mm} \\
(0.010 \mathrm{in} .)\end{array}$ & $\begin{array}{l}\$ S 0.25 \mathrm{~mm} \\
(0.010 \mathrm{in} .)\end{array}$ & $\begin{array}{l}S S, 0.25 \mathrm{~mm} \\
(0.010 \mathrm{in} .)\end{array}$ \\
\hline Slot Type & Wirewrap & Wirewrap & Wirewrap & Wirewrap & Wirewrap & Wirewrap \\
\hline Screen Length & $4.6 \mathrm{~m}(15 \mathrm{ft})$ & $4.6 \mathrm{~m}(15 \mathrm{ft})$ & $4.6 \mathrm{~m}(15 \mathrm{ft})$ & $4.6 \mathrm{~m}(15 \mathrm{fr})$ & $4.6 \mathrm{~m}(15 \mathrm{f})$ & $4.6 \mathrm{~m}(15 \mathrm{f})$ \\
\hline $\begin{array}{l}\text { Screen Interval } \\
\text { bgs }\end{array}$ & $\begin{array}{c}17.5-22.1 \mathrm{~m} \\
(57.5-72.5 \mathrm{ft})\end{array}$ & $\begin{array}{c}17.5-22.1 \mathrm{~m} \\
(57.5-72.5 \mathrm{ft})\end{array}$ & $\begin{array}{c}18.1-22.7 \mathrm{~m} \\
(59.5-74.5 \mathrm{ft})\end{array}$ & $\begin{array}{c}17.4-22.0 \mathrm{~m} \\
(57.0-72.0 \mathrm{ft})\end{array}$ & $\begin{array}{c}17.2-21.6 \mathrm{~m} \\
(56.5-71.5 \mathrm{ft})\end{array}$ & $\begin{array}{l}17.4-22.0 \mathrm{~m} \\
(57.0-720 \mathrm{ft})\end{array}$ \\
\hline Silt Trap & No & No & No & No & No & No \\
\hline Filter Pack Type & Lone Suar & Lone Star & Lone Star & Lone Star & Lone Star & Lone Star \\
\hline Mesh Sieve Size & $16-40$ & $16-40$ & $16-40$ & $16 \cdot 40$ & $16 \cdot 40$ & $16-40$ \\
\hline Filter Pack Interval & $\begin{array}{c}16.3-221 \mathrm{~m} \\
(53.5-72.5 \mathrm{ft})\end{array}$ & $\begin{array}{c}16.5-22.4 \mathrm{~m} \\
(54.0-73.5 \mathrm{ft})\end{array}$ & $\begin{array}{c}16.5-22.4 \mathrm{~m} \\
(54.0-73.5 \mathrm{fi})\end{array}$ & $\frac{16.5-22.1 \mathrm{~m}}{(54.0-725 \mathrm{ft})}$ & $\begin{array}{c}16.3-22.0 \mathrm{~m} \\
(53.5-72.0 \mathrm{ft})\end{array}$ & $\begin{array}{c}16.5-22.0 \mathrm{~m} \\
(54.0-72.0 \mathrm{f})\end{array}$ \\
\hline Primary Seal & Grout & Grout & Grout & Grout & Grout & Grout \\
\hline Secondary Seal & Bentonite & Bentonite & Bentonite & Bentonite & Bentonite & Bentanile \\
\hline Surface Completion & Aboveground & Aboveground & Belowground & Belowground & Belowground & Belowground \\
\hline Pump Type & Redi-Flo2 & Redi-Flo2 & Redi-Flo2 & Redi-Flo2 & Redi-Flo2 & Redi-Flo2 \\
\hline $\begin{array}{l}\text { HSU Unit and } \\
\text { Depth of Casing }\end{array}$ & $\begin{array}{l}15 t / 22.1 \mathrm{~m} \\
(72.5 \mathrm{fi})\end{array}$ & $\begin{array}{l}1 \mathrm{siv} 22.1 \mathrm{~m} \\
(72.5 \mathrm{f})\end{array}$ & $\begin{array}{c}151227 \mathrm{~m} \\
(74.5 \mathrm{ft})\end{array}$ & $\begin{array}{l}151 / 22.0 \mathrm{~m} \\
(720 \mathrm{ft})\end{array}$ & $\begin{array}{l}1 \mathrm{l} / 21.8 \mathrm{~m} \\
(71.5 \mathrm{ft})\end{array}$ & $\begin{array}{c}1 \mathrm{si} 22.0 \mathrm{~m} \\
(72.0 \mathrm{fl})\end{array}$ \\
\hline Date Completed & $10 / 01 / 90$ & $10 / 0990$ & $10 / 11 / 90$ & $10 / 25 / 90$ & $10 / 17 / 90$ & 10,2290 \\
\hline
\end{tabular}

1.7 


\subsection{Contaminants of Concern in Groundwater}

In March 1990, DOE assumed responsibility for the Phase II site characterization at LEHR. The purpose was to continue to support ongoing characterization and assessment of possible environmental impacts, remediation of soil and groundwater, and decontamination and decommissioning of buildings, as required at the LEHR site. The goal was to further characterize potential contaminant sources and evaluate the geologic and hydrologic relationships at the site. The design of monitoring wells and suitability of sample collection equipment were evaluated with respect to contaminants of concern at LEHR. Monitoring well designs and sample collection equipment were also evaluated with respect to suitability of the materials and design that would facilitate cost-effective collection of representative samples of groundwater contaminants.

Hazardous constituents, or indicators of potentially hazardous constituents related to past LEHR site operations, are divided into the following general categories: heavy metals, such as chromium, hexavalent chromium, barium, thallium, and selenium; anions, such as chloride, nitrate, phosphate, and sulfate; radionuclides, such as tritium, carbon-14, and strontium-90; and organics. The organic constituents of concern can be divided into volatile organic constituents (VOCs), such as 1,1-dichloroethane, 1,1-dichloroethene, 1,2-dichloroethane, methylene chloride, chloroform, benzene, and toluene; and semivolatile organic constituents, such as di-n-butylthalate, bis-phthalate, and diethylphthalate.

Table 1.2 summarizes the contaminants of concern and constituents of interest at LEHR. Most of these constituents were identified as possible contaminants of concern and were considered in the design of the groundwater sample collection system. Later sampling confirmed that new UCD wells were installed in areas where these contaminants were present at elevated levels above upgradient monitoring wells, or were confirmed by groundwater samples from Hydropunch ${ }^{\mathrm{TM}}$ samples. $^{\circ}$ 
Table 1.2. Contaminants of Concern and Constituents of Interest

Contamination Indicator Parameters:

Specific Conductance (field and lab) pH (field and lab)

Temperature

Total Organic Halogen (TOH)

Total Organic Carbon (TOC)

Gross Beta

Groundwater Quality Parameters:

Chloride

Total Dissolved Solids

Sulfate

Potassium

Sodium

Nitrate

Inorganic Drinking Water Parameters:

Barium

Selenium

Thallium

Chromium

Hexavalent Chromium

Turbidity

Organic Drinking Water Parameters:

1,1-Dichloroethane

Methylene Chloride

1,1-Dichloroethene

Benzene

1,2-Dichloroethane

Toluene

Chloroform

Di-n-butylthalate

Diethylphthalate

Bis-phthalate

Radionuclides:

Tritium

Carbon-14

Strontium-90 


\subsection{Monitoring Well Construction and Development}

\subsection{Basis for Improved Well Design}

High turbidity problems in Phase I, with sitewide assessment team (SWAT) monitoring wells that were screened in the first HSU and with large water level fluctuations during the year, necessitated design changes in the screened intervals of Phase II wells. The goal for the monitoring well design was one that would allow for hydrologic testing and reduce the turbidity to minimize the impact of sampling on the quality of the samples collected. In the previously installed monitoring wells, the turbidity exceeded regulatory levels for drinking water during the purging cycle and sometimes the sampling cycle. Available expertise and ASTM standards were used as the bases to design, construct, and develop the monitoring wells (ASTM 1990a and b; Nielsen 1991; Williams 1981). Literature was reviewed to identify people working in groundwater monitoring. Such people aided in identifying sampling pumps and their proper placement, and the deployment methods used to collect representative groundwater samples at LEHR.

\subsection{Construction}

The earlier wells installed in Phase I and for the SWAT were installed at shallower depths, particularly in the HSU-1 unit. To accommodate seasonal water level fluctuations, wells screened in the HSU-1 unit were installed slightly deeper than earlier wells. The HSU-2 wells in Phase I were completed to $27.3 \mathrm{~m}$ (90 ft) bgs with 4.6-m (15-ft) screens, whereas the Phase II wells installed in 1990 were redesigned to $36.4 \mathrm{~m}$ (120 ft) bgs with 7.6-m (25-ft) screens spanning more than 75 percent of the HSU-2 water-production zone. Screened interval depth was selected to allow sample collection during summer and fall when water levels were at their lowest. Long screened intervals allowed measurement of the hydraulic conduction and transmission characteristics of each unit.

\subsubsection{Well Screen and Filter Pack Design}

Before 1990, wells were typically constructed with slotted 5.1-cm (2-in.) diameter (for the Phase I wells) or 10-cm (4-in.) diameter PVC casing used as well screen and PVC casing (for the SWAT wells). The 10-cm (4-in.) diameter casing was selected for newer wells to allow for a greater number of hydraulic testing methods. In addition, the larger diameter casing permitted the use of a larger variety of pumps for development and sampling to facilitate well development with conventional 
methods. It also made the access easier for tools to measure water level and for the placement of in situ instrumentation. To reduce turbidity and expedite development in both zones, Phase II monitoring wells were constructed of 10-cm (4-in.) diameter, 304 stainless steel, continuous wirewrap screen (Bikis 1979; Clark and Turner 1983; Jackson 1983; Rinaldo-Lee 1983; Paul et al. 1988; Schalla and Walters 1989; Nielsen 1991). This 304 screen type has a larger open area than other types, even in the smaller slot sizes selected (Nielsen 1991). Slot size chosen for wells screened in HSU-1 was $0.0254 \mathrm{~cm}(0.010 \mathrm{in}$.) (called 10-slot); an appropriate filter pack Lonestar $1 \mathrm{C}$ sand (a 16-40 mesh gradation) was selected on the basis of recommendations set forth in consensus society standards and recognized publications (ASTM 1990a and b; Nielsen 1991; Schalla and Walters 1989). Wells screened in HSU-2 used 0.05 -cm (0.020-in.) slot openings of 10-cm (4-in.) diameter, stainless steel, continuous wire-wrap screen with a number 2/12 filter pack sand (a 12-20 mesh gradation). Schedule 40 PVC casing, $10 \mathrm{~cm}$ (4 in.) in diameter, was used from the top of the screened interval to above the ground surface for all wells to reduce the well cost while retaining the desirable characteristics of stainless steel wire-wrap screen. Flush-threaded casing, conforming to ASTM F480-90, was used for all screen and casing. To avoid a stagnant zone, no sediment trap or silt trap was added to the bottom of the well (Nielsen 1991; Yu 1989).

\subsubsection{Material/Contaminant Compatibility}

During the 1980s, the environmental community expressed concerns that certain monitoring well materials might leach or adsorb contaminants to (or even absorb contaminants from) groundwater. Many studies were conducted under laboratory and field conditions. Several of these studies are referenced in Nielsen 1991. Although Phase II groundwater monitoring wells at the LEHR site were based on the recommended practice in ASTM D5092-90, they also comply generally with the primary federal guidance document (EPA 1986). The 1986 Technical Enforcement Guidance Document (TEGD) recommends that all well construction materials be composed of inert material, such as fluorocarbon resin or stainless steel. More research, published after issuance of that TEGD, showed that PVC was a superior or equal choice, depending on the constituents contained in the groundwater (Barcelona and Helfrich 1986; Barcelona et al. 1988; Dunbar et al. 1985; Gillham and Ohannesin 1990; Miller 1982; Nielsen 1991; Parker 1992).

Field studies at hazardous waste sites have shown that types 304 and $304 \mathrm{~L}$ stainless steel wells may, for many months, leach chromium in quantities of 10 to 30 parts per billion (Smith 1988; Smith el al. 1989; Schalla et al. 1988a; Chamness et al. 1990). In these studies, groundwater types ranged from calcium or sodium-calcium/carbonate types to calcium sulfate types with $\mathrm{pH}$ values ranging from 6.9 to 8.2. In general, conditions at LEHR fall within these ranges. A study under laboratory conditions shows that type 304 stainless steel wire wrap leached chromium, while type 
316 stainless steel wire wrap had a slight tendency to absorb chromium (Parker 1992). Based on this data, type 304 was selected for the well screen. It was decided it would be preferable to have a false positive for chromium reported with 304 stainless steel leaching than a false negative caused by adsorption on $316 \mathrm{~L}$ stainless steel well screen. Certain radioisotopes are absorbed by $316 \mathrm{~L}$ stainless steel, including strontium-85, cesium-137, and selenium-75 (Raber et al. 1983). However, no specific evidence showed that sorption would occur for the isotopes at LEHR. Other research shows that residence time in the short pathway through the well screen should not have any effect on the sample (Robin and Gillham 1987). The casing above the stainless steel screen was Schedule 40, flushthreaded PVC. Based on many studies of sorption and leaching tests, the sample bias effects due to adsorption or leaching with well casing materials, including PVC, are negligible (Barcelona et al. 1983; Reynolds and Gillham 1985). Therefore, PVC was chosen as the lowest cost casing material compared to other available materials (such as stainless steel, fluoropolymers, and epoxy-reinforced fiberglass). Neither PVC nor stainless steel was a concern with respect to the organic volatiles found at the site (Barcelona et al. 1983; Barcelona et al. 1988; Gillham and Ohannesin 1990; Parker 1992; Reynolds and Gillham 1985).

\subsubsection{Completion Issues}

To further prevent migration of fines from fine-grained layers of sediment above the first HSU-2 unit, and thereby reduce turbidity, well screen tops were kept approximately $70 \mathrm{~cm}(2 \mathrm{ft})$ below the top of the sand and gravel zone. However, to obtain flow from that $70-\mathrm{cm}(2-\mathrm{ft})$ interval, while holding back fine-grained sediments in the formation above, the coarse filter pack extended $70 \mathrm{~cm}$ ( $2 \mathrm{ft}$ ) above the top of the well screen and a $91-\mathrm{cm}$ (3-ft) layer of the Lonestar $1 \mathrm{C}$ sand was used as a secondary filter in accordance with ASTM D5092-90. The bentonite slurry and fine sand was used as a secondary seal between the cement/bentonite grout and the filter pack. In HSU-2 Wells UCD-15 and 16 , a $152-\mathrm{cm}$ (5-ft) thick layer of bentonite pellets was used in lieu of the secondary filter pack as a barrier to the Volclay bentonite grout. This process prevented invasion of the sand pack by the 2 to 5 percent bentonite/cement grout mixture that filled the space above the pellets to just below ground surface. For the same reason, in HSU-1 wells, $0.64-\mathrm{cm}(0.25-\mathrm{in}$.) diameter bentonite pellets were added to a depth of $91 \mathrm{~cm}$ ( $3 \mathrm{ft}$ ) above the filter packs.

Installation was accomplished by drilling all HSU-1 wells with hollow stem auger drills and all of the HSU-2 wells with air rotary drills. These techniques were selected to minimize the alteration of hydraulic characteristics of the formation (Nielsen 1991; Schalla 1986). Screen and casing were lowered into the well and kept in tension during placement of filter pack and sealants in the annulus. Filter pack sand was continuously fed by a special funnel feed device mounted on the drill rig derrick 
as the tremie was pulled back. Pellets and grouts were placed using tremies to prevent bridging of materials in the well annulus. These fillers also prevented the voids and casing damage associated with bridging.

Phase II monitoring wells (UCD-15 through UCD-20) were completed with an above-ground, locking steel, protective casing or were flush-ground, watertight, locking well boxes (UCD-21 through UCD-24). Installations flush with the ground were placed in high-traffic areas to prevent damage to the wells. The ground surface was sloped away from the wellhead to prevent downward migration of water from precipitation or runoff.

\subsection{Development}

During October and November of 1990 , development occurred in two stages for each well. Development first began after placement of the filter pack, but before the placement of the annular sealants. Wells were swabbed or surged to help settle the filter pack and, as settling occurred, additional filter pack was added, as needed. This type of surging is very effective for settling the filter pack because of the high velocities created in the well (Schalla and Landick 1986; Paul et al. 1988; Sevee and Maher 1989). After construction, a combination of surging and cleaning using a bailer and subsequent pumping with a submersible pump at 3.8 to $26.5 \mathrm{~L}$ per min ( 1 to $7 \mathrm{gpm}$ ) continued for a few hours to reduce well turbidity by removing fine-grained materials from the formation (Schalla 1986; Winegardner 1990). Initial turbidities in the HSU-2 wells were above 200 nephelometric turbidity units (NTU) during the first 10 min of pumping and gradually declined to less than 15 NTU at the end of development. Similar successes in reducing turbidity occurred in the HSU-1 wells, although some were nearly 50 NTU after development; two were less than 5 NTU. 


\subsection{Pump Selection Process}

\subsection{Sampling Process Considerations}

Groundwater sample collection from monitoring wells requires two basic activities, purging and sampling (sometimes referred to as cycles). Purging is the activity of removing stagnant water that is in the well casing and screen (and sometimes in the filter pack surrounding the well screen) that must be removed before sampling in order to obtain a representative sample from the water-bearing layers. Excluding wells with very high groundwater velocities, (such as $30.3 \mathrm{~m}$ or $100 \mathrm{ft}$ per day), purging most monitoring wells throughout the entire screened interval is a necessity for the purpose of removing stagnant water. This process is necessary to obtain representative samples, as is well-established in the literature by hundreds of papers representing tens of thousands of samples for both organic and inorganic compounds. Sample collection (or sampling) is the removal of specified quantities of groundwater from the well (after purging) to obtain samples for analysis. The goal of purging and sampling is to obtain analyses of constituents that are representative of the formation groundwater composition at the well site. To minimize costs and equipment in the wells, a single device to perform both activities, rather than two separate devices, was the desired choice.

\subsection{Categories of Sample Collection Devices}

Three broad categories of sample collection devices are described in the literature (Pohlmann and Hess 1988; Nielsen and Yeates 1985; Anderson 1977; and Herzog et al. 1991). The three sample collection categories used for this report are 1) grab mechanisms, 2) suction lift mechanisms, and 3) variable discharge rate pumps.

Grab mechanisms, such as bailers and syringe pumps, simply deploy a sampling device to the sample interval, where it is passively or actively filled with water. Suction lift mechanisms include centrifugal and peristaltic pumps that pull the sample up to the surface by decreasing the head, or pressure, over the sample. The variable discharge rate pump category includes both variable displacement and positive displacement mechanisms (typically, all are called pumps) and consists of eight commonly used variable discharge rate pumps. These pumps include gas-lift devices, gas-drive (also called gas-displacement) devices, gas-operated bladder pumps (also called squeeze pumps or 
diaphragm pumps), inertial lift pumps, electric (centrifugal) submersible pumps, gear-drive pumps, progressive cavity pumps (also called helical rotor pumps), and internal combustion-driven piston pumps.

\subsection{Pump Performance Criteria}

Purging and sampling activities have practical considerations, regardless of the sampling device or pump type used. Where appropriate, a discussion of these considerations, which form the criteria for sample pump evaluation and selection in this report, is presented with reference to a specific pump type in this section. This section includes a generic discussion of these issues related to any type of pump.

The practical considerations for purging and sampling, using one pump to perform both functions, were used as criteria in the selection process and belong in four categories that include:

1. proper deployment in well

- ability to properly deploy pump intake in relation to geohydrologic conditions (such as depth to water or permeable layers)

- adequate accessibility and deployment in relation to well construction and development (that is, inside casing diameter, screen length, slot size, screen type, or turbidity during purging)

2. physical performance capabilities

- adequate lift and discharge capabilities

- appropriate pump flow rate control and range

3. ability to obtain a representative sample

- minimal alteration by pump construction materials

- minimal alteration of sample chemistry caused by purging

- minimal alteration of samples by pump operation during sampling cycle

4. efficiency

- ease of field sampling operation

- ease of cleaning during maintenance and before installation (not a criterion in this report)

- the maintenance record (not a criterion in this report) reflecting reliability and durability of the sample collection pump. 
The reasons for excluding types of sampling devices or pumps are presented in the following discussion of deployment.

\subsubsection{Proper Deployment in Wells}

Proper deployment of sampling devices in the monitoring wells requires an understanding of the hydrogeology, the layers that transport the contaminants of interest, and the vertical distribution of the contaminants. The placement of pumps in screened intervals may have greatly affected (order of magnitude) the concentration of contaminants and general water quality parameters during purging (Barcelona and Helfrich 1992; Schalla 1992). Even small-scale vertical variations in well-screen inflow rates and placement of pump intakes may have large effects on the capability to collect representative groundwater samples (Gibs et al. 1993). The lack of discrete sampling intervals and the determination of equivalence intervals can lead to erroneous results and conclusions (Barcelona and Helfrich 1992; Barcelona et al. 1994).

Although the wells at LEHR could be divided into two depth-to-water ranges of 18.2 to $21.2 \mathrm{~m}$ (60 to $70 \mathrm{ft}$ ) and 27.3 to $30.3 \mathrm{~m}(90$ to $100 \mathrm{ft}$ ), an average depth of $27.3 \mathrm{~m}(90 \mathrm{ft}$ ) was used for discussion of the best-suited sample collection pumps. The depth-to-water measurement is important because it represents the hydraulic head and, therefore, the lift capability the collection pump must be able to exert to obtain samples from the greatest depth.

\subsubsection{Candidate Selection Process}

To simplify the evaluation process, the greatest anticipated depth the pump would be set was $27.3 \mathrm{~m}(90 \mathrm{ft})$. At this depth, many types of pumps would not be able to purge stagnant water from wells at reasonable rates or to obtain representative samples. Agitation or high flow rates in some wells screened in HSU-1 with geologic units rich in silt and clay may produce unacceptably high turbidity and suspended particles (that is, greater than 5 NTU) and result in unrealistically high levels of metals (Puls et al. 1992; Powell and Puls 1993). The inability of grab mechanisms (such as bailers) to obtain samples without causing high turbidity and unrepresentative samples, the possible damage to a sand pack stabilized during development, and the potential spread of contamination because of spillage during purging and sampling prohibited further consideration of these sample collection devices as suitable to accomplish both purging and sampling (Puls and Powell 1992; Barcelona and Helfrich 1992). Suction-lift mechanisms (centrifugal and peristaltic pumps) were precluded from further consideration because they can draw samples only from very shallow depths [such as, $7.6 \mathrm{~m}(25 \mathrm{ft})$ ] and produce erroneous results when pulling the sample up to the surface by decreasing the pressure over the sample (Barcelona et al. 1984; Imbrigiotta et al. 1988; Puls and 
Barcelona 1989a and b). Of the eight variable discharge pumps, two [the internal combustion (IC) pump and the gas-lift pump] are not suitable for most sampling applications because an interface exists between the drive gas and the water to be sampled. This situation causes a potential for loss of dissolved gases and volatile constituents across the interface, and for contamination to enter the sample water from the drive gas (Barcelona et al. 1985).

Therefore, based on reports in the literature and the proper deployment requirement, the first two categories of sampling devices, grab and suction-lift mechanisms, were eliminated from further consideration. Two of the variable discharge pump types were eliminated as sampling devices, but were considered with respect to the other criteria. The remaining six variable discharge rate pumps under discussion (centrifugal submersible pump, bladder pump, piston pump, progressive cavity pump, gear-driven pump, and inertial lift pump) and their operational characteristics, relevant to LEHR, are shown in Table 3.1.

Table 3.1. Operational Characteristics of Purging and Sampling Devices

\begin{tabular}{|c|c|c|c|c|c|c|}
\hline & $\begin{array}{c}\text { Centrifugal } \\
\text { Submersible } \\
\text { Pump } \\
\end{array}$ & $\begin{array}{l}\text { Bladder } \\
\text { Pump } \\
\end{array}$ & $\begin{array}{l}\text { Single-Acting } \\
\text { Piston Pump }\end{array}$ & $\begin{array}{c}\text { Helical Rotor } \\
\text { Submersible } \\
\text { Pump } \\
\end{array}$ & $\begin{array}{c}\text { Gear-Drive } \\
\text { Submersible } \\
\text { Pump } \\
\end{array}$ & $\begin{array}{c}\text { Inertial } \\
\text { Lift Pump }\end{array}$ \\
\hline \multicolumn{7}{|l|}{ Approximate } \\
\hline $\begin{array}{l}\text { Diameter } \\
\text { (inches) }\end{array}$ & 1.81 & 1.5 & 1.7 & 1.75 & 1.75 & 0.75 \\
\hline \multicolumn{7}{|l|}{ Maximum } \\
\hline Lift (feet) & 270 & 1000 & 400 & 180 & 125 & 260 \\
\hline $\begin{array}{l}\text { Maximum } \\
\text { Design Flow } \\
\text { rate (gpm) }\end{array}$ & 9.0 & 3.5 & 5.0 & 1.2 & 1.4 & 4.0 \\
\hline $\begin{array}{l}\text { Typical Flow } \\
\text { Rate @ 90ft }\end{array}$ & & & & & 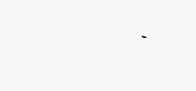 & \\
\hline $\begin{array}{l}\text { L/min [Lift } \\
\text { (gpm)] }\end{array}$ & $\begin{array}{c}29 \\
\left(7.7^{\mathrm{gpm}}\right)\end{array}$ & $\begin{array}{c}5 \\
(1.3 \mathrm{gpm})\end{array}$ & $\begin{array}{c}18 \\
(4.7 \mathrm{gpm})\end{array}$ & $\begin{array}{c}3 \\
(0.8 \mathrm{gpm})\end{array}$ & $\left(\begin{array}{c}1 \\
(0.3 \mathrm{gpm})\end{array}\right.$ & $\begin{array}{c}10 \\
(2.6 \mathrm{gpm})\end{array}$ \\
\hline $\begin{array}{l}\text { Minimum } \\
\text { Achievable } \\
\text { Flow } \\
\text { [Discharge } \\
\text { rate (gpm)] }\end{array}$ & $<0.026$ & $<0.026$ & 0.25 & $<0.026$ & $<0.026$ & $<0.026$ \\
\hline Power Source & Electric & Pneumatic & $\begin{array}{l}\text { Pneumatic/ } \\
\text { Mechanical }\end{array}$ & Electric & Electric & $\begin{array}{l}\text { Manual, } \\
\text { Electric, or } \\
\text { IC Engine }\end{array}$ \\
\hline
\end{tabular}




\subsubsection{Site Specific Characteristics for Candidate Pumps}

The accessibility and ease of pump deployment in monitoring wells at LEHR are practical limitations related to the inside diameter of well screen, screen length, slot size, and turbidity during purging. At a minimum, the pump must be small enough in diameter to fit inside the well screen and casing. Where needed, the pump should also allow enough clearance for water-level measurements and installation of subsurface monitoring devices. Hydraulic conductivities in both HSU units can sustain discharge rates of $5 \mathrm{gpm}$ for properly constructed monitoring wells with sufficient screen length. Well construction would include Schedule 40 PVC casing and stainless steel well screen with diameters of $10 \mathrm{~cm}$ ( $4 \mathrm{in}$.). The volume contained in a given length of a 10-cm (4-in.) well is four times greater than that for a 5-cm (2-in.) well (Rinaldo-Lee 1983). Also, the entrance velocities at the well screen are inverse to the square of the well diameter, and higher purge rates are allowable in the larger 10-cm (4-in.) diameter wells. Therefore, the purge volumes are much larger in the wells with the larger diameter. The well screen diameter and length are important for determining well equivalent volumes of purge water to be removed from the screened interval (SC); the screened interval and the filter pack (SPSC); or the screened interval, the filter pack, and the volume of water in the casing above the screen (BV) (Barcelona et al. 1994; Schalla 1993).

The well screen diameter, length, and slot size or percentage of open area are important in determining the flow velocity in the slots and in the well during pumping which, in turn determines appropriate purging and sampling rates (Puls et al. 1992; Powell and Puls 1993; Barcelona et al. 1994). If approximately $1 \mathrm{~L} / \mathrm{min}(0.26 \mathrm{gpm})$ is an appropriate purge rate for a 5 -cm (2-in.) diameter, $152.4-\mathrm{cm}(5-\mathrm{ft})$ long, $6.25-\mathrm{mm}(0.010 \mathrm{in}$.) continuous wire wrap slot size, stainless steel casing in formations having hydraulic conductivities ranging from $10^{-2}$ to $10^{-3} \mathrm{~cm} / \mathrm{sec}$ (Barcelona et al. 1994), then it also should be true that a 10.2-cm (4-in.) diameter screen should be purged at $4 \mathrm{~L} / \mathrm{min}(1.04 \mathrm{gpm})$ for every $152.4 \mathrm{~cm}(5 \mathrm{ft})$ of screen. The wells in HSU-1 have $4.6-\mathrm{m}$ (15- $\mathrm{ft}$ ) screens and could be purged at up to $12 \mathrm{~L} / \mathrm{min}(3.12 \mathrm{gpm})$. For larger screen slot sizes, such as $0.050 \mathrm{~cm}(0.020 \mathrm{in}$.) and correspondingly coarser filter packs in wells screened in HSU-2, it should be possible to double the purge rates [that is, to $8 \mathrm{~L} / \mathrm{min}(2.08 \mathrm{gpm})$ ] for each $1.5 \mathrm{~m}(5 \mathrm{ft})$ of screened interval, if the water-bearing units have hydraulic conductivities equal to or greater than $10^{-2} \mathrm{~cm} / \mathrm{sec}\left(4 \times 10^{-3} \mathrm{in} / \mathrm{sec}\right)$. The wells in HSU-2 have $7.5-\mathrm{m}(25-\mathrm{ft})$ screens and can be purged at a rate up to $40 \mathrm{~L} / \mathrm{min}(10.4 \mathrm{gpm})$.

\subsubsection{Specific Deployment Issues}

To reduce the time necessary to remove the required amount of purge water from a well, it is preferable to purge at as high a rate as possible without causing undesirable turbidity during purging 
and sampling. This reduction in time also reduces effort, cost, and safety hazards. For the deeper HSU-2 wells that year round have at least a few feet of water in the casing above the screened interval, the wells should be purged (as a minimum requirement) with the pump intake located 3 to 5 well diameters above the screen to eliminate the need to dispose of large volumes of purge water and to reduce the amount of time required for purging. The placement of the pump at this location eliminates the need to purge the column of stagnant water located above the well screen. This statement is true, if at least $0.5 \mathrm{~m}(1.5 \mathrm{ft})$ of drawdown occurred or the pump was initially lifted $0.5 \mathrm{~m}(1.5 \mathrm{ft})$, then slowly lowered just prior to sampling (Barcelona et al. 1985; Robin and Gillham 1987; Barcelona and Helfrich 1992; Kearl et al. 1992; Schalla 1992; Unwin and Maltby 1988; Maltby and Unwin 1992). A primary consideration for all wells at the LEHR site is to ensure the isolation of the stagnant water above the well screen. During isolation, the purge rate should lower the stagnant water column to less than one foot. During subsequent phases, this purge volume was planned to be further reduced by displacement or isolation devices (Schalla 1992; Barcelona and Helfrich 1992; Maltby and Unwin 1992; Schalla 1993). The rate and the volume of stagnant water to be removed during purging influenced the decision regarding which pump was considered best suited for sampling under various design scenarios.

To obtain consistent and representative results, the ideal location of the pump intake for the shallower HSU-1 wells would be opposite the most permeable layer containing the highest concentration of contaminants of concern. In fact, the vertical distribution of permeability opposite the screened interval can be accurately and easily determined (Hall et al. 1991; Hall and Raymond 1992; Hall 1993). Setting the pump intake opposite the permeable zone or zones is not practical because vertical variations have not been studied adequately in each well. Also, seasonal water levels decline to such an extent that a few wells go dry and the primary permeable zones are no longer saturated (Robbins and Martin-Hayden 1991; Martin-Hayden et al. 1991).

\subsubsection{Purging and Sampling Rate Issues}

Although it may be true that certain zones exist within the subsurface where hydrogeology-based sampling would be advantageous (Gibs et al. 1993; Barcelona and Helfrich 1992; Gibs and Imbrigiotta 1990), such sampling has not been done. However, site experience and empirical data guided purging and sampling protocols. In general, wells should be pumped at rates that do not cause substantial drawdown from the mid-screen portion of a well and that efficiently remove a consistent number of purge volumes from each well prior to sampling (Barcelona et al. 1994). At the time of this evaluation, it was decided that a minimum number for all monitoring wells should be three to five equivalent volumes (that is, five SC for HSU-1 wells and three SC for HSU-2 wells), if indicator parameters [such as, turbidity, redox potential, $\mathrm{pH}$, electrical conductivity, or dissolved 
oxygen in-line (flow through), or actual contaminants of interest] have stabilized within approximately 10 percent over at least two measurements (Garske and Schock 1986; Gibs and Imbriogiotta 1990; Barcelona et al. 1994). Although 1.2 equivalent volumes is possible, it was not considered an identifiable lower limit for the LEHR site because of insufficient data. With isolation and displacement devices that minimize the volume of water above and below the pump, the volume of purge water can be reduced to less than 10 percent of the required amount without such devices (Schalla 1992). Considering the obvious problems associated with collecting, transporting, storing, and disposing of the contaminated purge water, the use of isolation and displacement devices may have seemed like a good idea (Puls et al. 1992; Powell and Puls 1993). However, isolation was not considered in the selection of pumps; therefore, the minimum volume to be removed from HSU-1 wells with $4.6 \mathrm{~m}$ (15 ft) of well screen is approximately $284 \mathrm{~L}$ (75 gal) each time the well is purged. In the case

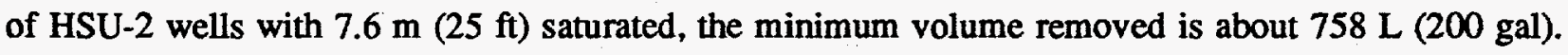
Therefore, it was desirable to have a pump that could purge about $190 \mathrm{~L} \mathrm{(50} \mathrm{gal)} \mathrm{in} \mathrm{as} \mathrm{little} \mathrm{as}$ $10 \mathrm{~min}$, requiring a discharge rate of $19 \mathrm{~L} / \mathrm{min}$ or $5 \mathrm{gpm}$.

In addition, the collection procedures recommended at the time included operating pumps so the sampling flowrate did not pulsate, or exceed $300 \mathrm{ml} / \mathrm{min}$ ( $9 \mathrm{fl} \mathrm{oz/min})$, during volatile constituent sampling. Flow rates used while sampling for other constants could be greater before sampling for volatile constituents has been completed. This limitation was set as a practical upper limit for filling a 40-ml (1.2-fl oz) volatile organic analyte (VOA) sample vial. The literature review indicated a recommended sampling of $100 \mathrm{ml} / \mathrm{min}$ ( $3 \mathrm{fl} \mathrm{oz} / \mathrm{min}$ ); therefore, this rate was used as the lower limit for the selection process (Barcelona et al. 1985; Barcelona et al. 1983).

Because of the selection of the pump and corresponding sampling and purge rates, it has been inferred the ideal purge rate should be less than 0.2 to $0.3 \mathrm{~L} / \mathrm{min}(0.05$ to $0.08 \mathrm{gpm})$, regardless of well design and configuration (Puls and Powell 1992; Puls and Barcelona 1989a and b). More recent literature indicates that if wells are properly constructed and developed, purge rates can be determined specific to hydrologic conditions and well construction, including well diameter and screen length (Barcelona and Helfrich 1992; Gibs et al. 1993; Barcelona et al. 1994). Most wells, if properly constructed to standards (ASTM D5092), even in silt-rich formations, can be purged at rates much higher than $0.3 \mathrm{~L} / \mathrm{min}(0.08 \mathrm{gpm})$ without exceeding 5 NTU. Admittedly, some wells in certain formations will typically have higher turbidities, regardless of development, if the purging and sampling rate is high (Robin and Gillham 1987). The entrance velocity at the slots in the well screen will be a determining factor for the amount of turbidity; therefore, the length of screen, slot size (percentage of open area), sediment sump, and well diameter will be significant factors (Bikis 1979; 
Clark and Turner 1983; Dunbar et al. 1985; Gillespie 1992; Jackson 1983; Kill 1989; Paul et al. 1988; Rinaldo-Lee 1983; Schalla 1986; Schalla and Walters 1989; Schalla and Landick 1986; Sevee and Maher 1989; EPA 1975; Winegardner 1990; Williams 1981; Yu 1989).

\subsubsection{Physical Performance Capabilities}

To achieve variation in purging and sampling rates that are necessary for the 10.2-cm (4-in.) diameter wells, the pump must be able to discharge water at the surface over an extensive range of flow rates while purging. In 10.2-cm (4-in.) diameter wells, the range of discharge flow rates at the surface needs to be from as little as 0.1 to $0.3 \mathrm{~L} / \mathrm{min}(0.03$ to $0.08 \mathrm{gpm})$ for sampling volatiles to $19 \mathrm{~L} / \mathrm{min}(4.9 \mathrm{gpm}$ ) for purging. To achieve this end, pumps must have adequate lift and corresponding discharge capabilities to pump from a depth of approximately $27.3 \mathrm{~m}$ (90 ft). Discharge flow rates that span the range described are possible only with small diameter pumps at depths of $15.2 \mathrm{~m}$ (50 ft) or less (Nielsen and Yeates 1985; Pohlmann and Hess 1988). In small diameter pumps, the higher end of the discharge range typically is much less as the depth-to-water measurement increases.

\subsubsection{Capability of Obtaining a Representative Sample}

To obtain a representative sample, the pump construction material must be totally inert or inert to the extent that it will not significantly alter analyte concentrations as a result of loss from sorption, degradation, or chemical interaction with pump materials. The preferred materials were 300 series stainless steels (most commonly used types are 304 and 316L) and Teflon $\circledast$, actually polytetrafluoroethylene (PTFE) (Barcelona et al. 1985; Barcelona et al. 1983; Barcelona et al. 1988). Sampling equipment may include discharge tubing that is Teflon-lined. Rigid PVC is acceptable, but flexible PVC is not (Barcelona et al. 1985). The suitable materials include rigid PVC, 300-series stainless steel, and Teflon for most organic and inorganic compounds (Barcelona et al. 1985; Barcelona et al. 1988; Miller 1982; Parker 1992; Pearsall and Eckhardt 1987; Pohlmann and Hess 1988). Studies have shown that if adequate purging is done and sampling follows immediately, the nature of the materials will have no significant impact on water chemistry (Robin and Gillham 1987).

If purge rates are too high, the possibility of altering sample chemistry caused by purging with positive displacement sample pumps has been suggested (Puls and Powell 1992; Puls et al. 1992; Puls and Barcelona 1989a and b). The possibility exists of some volatile loss from groundwater by some sampling devices, including a few positive displacement devices. However, most variable discharge pumps (such as variable displacement and positive displacement pumps) perform purging and sampling functions without evidence of volatile loss. This statement is supported by numerous reports of relevant research in the scientific literature (Barcelona 1985; Barcelona et al. 1988; Garske 
and Schock 1986; Gass et al. 1991; Gibs and Imbrigiotta 1990; Gibs et al. 1993; Imbrigiotta et al. 1988; Knobel and Mann 1993; Liikala et al. 1988; Miller 1982; Muska et al. 1986; Panko and Barth 1988; Parker et al. 1993; Pearsall and Eckhardt 1987; Pohlmann and Hess 1988; Schalla et al. 1988b; Stolzenburg and Nichols 1985; Unwin 1984; Unwin and Maltby 1988).

Studies conducted by Gass et al. (1991) and Knobel and Mann (1993) concluded that low flow rate submersible centrifugal pumps can deliver representative groundwater samples. A study conducted by Paul and Puls (1992), comparing a low flow rate submersible centrifugal pump, a bladder pump, and a peristaltic pump, concluded the submersible centrifugal pump produced the fewest negative impacts when trying to obtain representative and reproducible groundwater samples at the particular site and wells investigated. Research performed by Yeskis et al. (1988) indicates that submersible impeller pumps perform similarly to bladder pumps when collecting samples for volatile organics analysis. Higher discharge rate submersible pumps also are capable of obtaining representative samples (Liikala et al. 1988; Muska et al. 1986).

\subsubsection{Pump Efficiency}

The efficiency of a device (that is, one that works better, faster, safer, and incurs fewer operational problems) is less easily quantified than the physical performance features. Therefore, descriptions of routine use, not first-time implementation, are discussed. Also, at the LEHR site, each sample collection pump is dedicated to a single well, which means the difficulties of installation or removal for maintenance and subsequent cleaning requires minimal discussion. Neither of these issues are considered as part of the criteria for this evaluation. The primary concern, relative to efficiency, is the ease of system operation in the field by the user, including two primary activities, purging and sampling.

\subsection{Choice of Sampling Pump}

Previously discussed limitations of other sampling devices (grab mechanisms and suction lift mechanisms) in this report (Section 3.3.1) caused their removal from further discussion because they are either not suitable for the purging and sampling performance range of interest or for the conditions that exist in the monitoring wells at the LEHR site. By eliminating these two categories of sampling devices and by specifying the approximate performance ranges used by the six pumps remaining to be evaluated, criteria were simplified. Furthermore, based on the evaluation considerations in Section 3.3, it is apparent that only four criteria are necessary to evaluate the relative merits of 
the remaining six variable discharge rate pumps: bladder pumps, inertial lift pumps, centrifugal submersible pumps, gear-driven pumps, progressive cavity pumps, and internal combustion pumps. (Refer to Table 3.1.)

Proper deployment of the pump intake in relation to hydrogeologic conditions (that is, depth to water) and the well screen apparently could be accommodated by any one of the six pumps, if it has the ability to discharge water at the surface at rates specified for physical performance. For the purging cycle, issues related to inside diameter, screen length, slot size, and percentage of open area are collectively discussed, using the suggested upper physical performance capability to eliminate significant turbidity and ensure the representativeness of samples taken from the well. Based on the literature, all six pumps have the capability to obtain a representative sample and have pump construction materials that do not alter the samples during purging or sampling cycles. Therefore, chemical considerations were removed from final consideration. All of the pumps could be installed in 10-cm (4-in.) diameter wells with adequate clearance to allow for in situ monitoring devices or manual measurements. Thus, the questions that remained for the evaluation were:

1. Could the pump discharge water at the surface at rates from as low as $0.1 \mathrm{~L} / \mathrm{min}(0.026 \mathrm{gpm})$ or sampling up to $19 \mathrm{~L} / \mathrm{min}$ (4.94 $\mathrm{gpm}$ ) for purging?

2. Is the pump easy to use for purging and sampling (that is, how is it better at controlling flow rates, faster [up to the limits required], or safer to use)? For example, how easily can discharge flow rates be controlled?

Based on the literature review, only one sample collection pump fully met the requirements to satisfy the desired purge performance range, even though several pumps could obtain representative groundwater samples consistently and reliably. This sample collection pump, a variable frequency submersible pump, had recently become available by Grundfos. The commercial unit available today is called the Grundfos MP1 Redi-Flo2 ${ }^{\mathrm{TM}}$. The units used at the site were precursors (actually beta units) and simply called Grundfos MP1 pumps.

Although most of the six pumps are easy to use, this submersible pump was the easiest. For an electrically powered system, the low-discharge centrifugal submersible pump was very easy to control because hookups to power and the control box are simple and take only seconds to complete. Because this system provides a continuous stream of water, filling sampling bottles is quite easy. Adjusting the flow rate is almost as easy as operating a water faucet. In addition, at the DOE Hanford Site in Washington, a power monitor is connected for the Ground-Water Surveillance Program during 
sample collection. This system is recent and more complex, but it increases the safety factor for operating electrical devices near water. For the procedures used at LEHR and the ease of access to all wells, the power monitor unit was not thought necessary. 


\subsection{Performance of Monitoring Wells, \\ Pumps, and Accessories}

The technical performance of monitoring wells, pumps, and accessories is discussed separately in the following sections; however, the performance is actually a composite of all components. If the monitoring wells are not properly designed, constructed and developed, it does not make any difference what type of sampling pump was chosen. With improper well design, the groundwater samples would be turbid and not representative of groundwater chemistry; sampling would be difficult, or impossible, for most constituents. Also, frequent maintenance of the well would be required to remove the buildup of fines and possibly biological growth in the well screens. If a less efficient pump or sampling device is chosen, cost of contaminant spillage on the ground or personnel increases sampling costs and reduces efficiency. Installation and operational costs could be higher for systems less easy to install, maintain, and use. The enhanced groundwater sample collection system includes all of the improved components.

\subsection{Monitoring Well Performance}

As expected, monitoring wells performed very well. Unlike earlier wells that frequently had turbidities in excess of $200 \mathrm{NTU}$, these new monitoring wells consistently had turbidities below 5 NTU during sampling and usually during purging. The exceptions during purging were short periods in two HSU-1 wells when the turbidity would occasionally reach approximately 50 to 90 NTU for about 20 to $30 \mathrm{sec}$ near the start of the purging cycle. Perhaps the best evidence for success of the new well designs is the turbidity that is currently observed during the sampling cycles. For example, in the May 1993 quarterly sampling at LEHR, the older UCD wells (such as, UCD-07 to UCD-14), which are sampled with bladder or submersible pumps, had turbidities ranging from 1.55 to 3.77 NTU and averaging 2.46 NTU. In contrast, turbidities in the newly designed wells (such as, UCD-15 to UCD-23), which are sampled with variable frequency submersible pumps, ranged from 0.14 to $2.39 \mathrm{NTU}$ and averaged $0.58 \mathrm{NTU}$. With the exception of one well, all turbidity values in the new wells were less than $1.0 \mathrm{NTU}$. In other quarterly samplings, the values may average somewhat higher, but the proportions are roughly the same. The older wells have turbidities averaging 5 to 10 times as high as the newer wells, probably because the older wells were not constructed with wirewrap well screen, have too coarse a filter pack and slot size for the HSU-1, and may not have been adequately developed during and following construction. 
For a period of time, water would accumulate in the above- and below-ground protective housings in the annulus between the PVC and the outer steel casing. After the fittings on the pump discharge lines were adjusted to prevent leakage, only one leakage issue remained. This issue was the possibility of accumulation of water in Christy boxes in below-ground wells or in an annulus between the PVC and steel casings caused by the leaking hose fitting. On January 22, 1991, the above-ground housings did not have a weep hole in the protective steel casing, as recommended in ASTM D5092-90 and other recognized documents for proper monitoring well design (Nielsen 1991). These weep holes were to have been drilled into the steel casing to allow fluids to drain from the annulus of the above-ground wells. Water had accumulated in the annulus of Well UCD-19, which may have occurred during the initial sampling of the well, when it was bailed, or during development. An alternative to weep holes is the improvement of the surface fittings on the discharge lines. This altemative was chosen to prevent accumulation of water in the annulus between the PVC and the outer steel casing,

The below-ground completions had special needs. Either the PVC casing threads had to be left in place to allow for a flush-threaded seal or another type of seal to prevent introduction of surface contamination into the well bore. The difficulty and expense of obtaining casings of different short lengths to construct the well on top with a threaded connection resulted in an agreement that Christy boxes could serve as the sole hydraulic barrier. The issue was finally resolved by agreeing that flushmounted, water-tight, locking well boxes will be installed in positive grout mounts in high traffic areas. Initially, none of the Christy boxes had gaskets or O-rings on the lid or lockdown bolts to prevent water from entering the Christy boxes through these gaps. To prevent surface water contamination, manhole covers and bolts at the site were provided with sufficiently leak resistant gaskets. In addition, special surface seal systems, called Dedicators, were later put on the PVC casing when the pumps and access ports were installed. These seals on the PVC casing are discussed in detail in the next section.

\subsection{Performance of Submersible Pump and Accessories}

On November 8, 1990, the Redi-Flo2 Pump Model No. MP1 was installed in 3 deep wells of the 10 new wells at the site. On January 22,1991 , the same model of pump was installed on the seven remaining shallow wells. The purging/sampling pumps are $4.6 \mathrm{~cm}$ ( $1.82 \mathrm{in}$.) outside diameter, 13-in. long, stainless steel mini-submersible pumps with a 4-wire motor lead and 0.625 -in. outside diameter all Teflon ${ }^{\circledR}$ discharge riser tubes. The pump uses a single-phase converter $230 \mathrm{~V}$ input that varies the voltage from 46 to 400 hertz. This variable speed motor allows discharge rate from approximately $50 \mathrm{ml} / \mathrm{min}(1.5 \mathrm{fl} \mathrm{oz} / \mathrm{min})$ to $25,000 \mathrm{ml} / \mathrm{min}(750 \mathrm{fl} \mathrm{oz} / \mathrm{min})$. The surface seal and 
pump support system consisted of a homemade cap made of PVC that did not form an airtight seal with the well. The cap also protruded nearly a foot above the top of the well. Later in August 1992, the wells were retrofitted with two accessory systems called Dedicator and Happy Hose to correct the problems described in the following paragraphs.

Initially, the system worked as planned with the exception of the following problems. These difficulties included leakage of the discharge fittings on the Grundfos pumps and the concomitant problem of water accumulation in the annulus between the PVC well casing and the protective steel housing.

The discharge hose fittings on the top cap surface seal or PVC header cap leaked. When the discharge extension hoses that extend from the top of the PVC header cap were originally installed with larger diameter, less flexible Teflon hoses, they did not leak during field discharge tests. However, these hoses could not be coiled up inside the protective steel casing or Christy boxes because of their diameter and lack of flexibility. These discharge hoses were replaced with smaller and more flexible polyethylene tubing. In February, a representative from Grundfos replaced these surface discharge hoses with reducer swage fittings and a $1.3-\mathrm{cm}(0.5-\mathrm{in}$.) outside diameter, Teflon-lined, polypropylene tubing. These new $1.82-\mathrm{m}$ (6-ft) long discharge hoses could be coiled up and stored in the protective housings, thus eliminating the inconvenience and safety concerns associated with disconnecting, transporting, and storing the larger diameter hoses. Apparently, the fittings in the new hoses were not tightened sufficiently or properly. The Grundfos installer indicated that a clearance of $10.2 \mathrm{~cm}(4.0 \mathrm{in}$.) between the steel cap of the protective housing and the top of the PVC in Well UCD-17 was insufficient to effectively coil up $1.82 \mathrm{~m}(6 \mathrm{ft})$ of discharge hose inside the protective housing. The installer cut off about 12.7 to $15.2 \mathrm{~cm}$ (5 to 6 in.) of PVC, using the internal pipe cutter, at a visit to the site in March 1991 to repair the leakage of the discharge fittings on the Grundfos pumps. Following repair of each of the discharge fittings, it was necessary to test the fitting to determine if the leakage had stopped. To do this required pumping at the maximum discharge rate of each pump for approximately $1 \mathrm{~min}$ while discharging a total of approximately $19 \mathrm{~L}$ (5 gal) of water. This effort proved to be a short-term solution because it was still difficult to store the long hoses in the spaces available.

The solution to this problem was equipment, known as the Dedicator, which consists of a surface well seal with quick connect multiport connections, an access port with a fused riser, a support cable, and a motor lead connected to the pump shown in Figure 4.1. In June 1992, when these new systems were added, it was discovered that one Redi-Flo2 pump needed replacement because of declining performance. Also, nine properly functioning Redi-Flo2 pumps were to be retrofitted with the new 


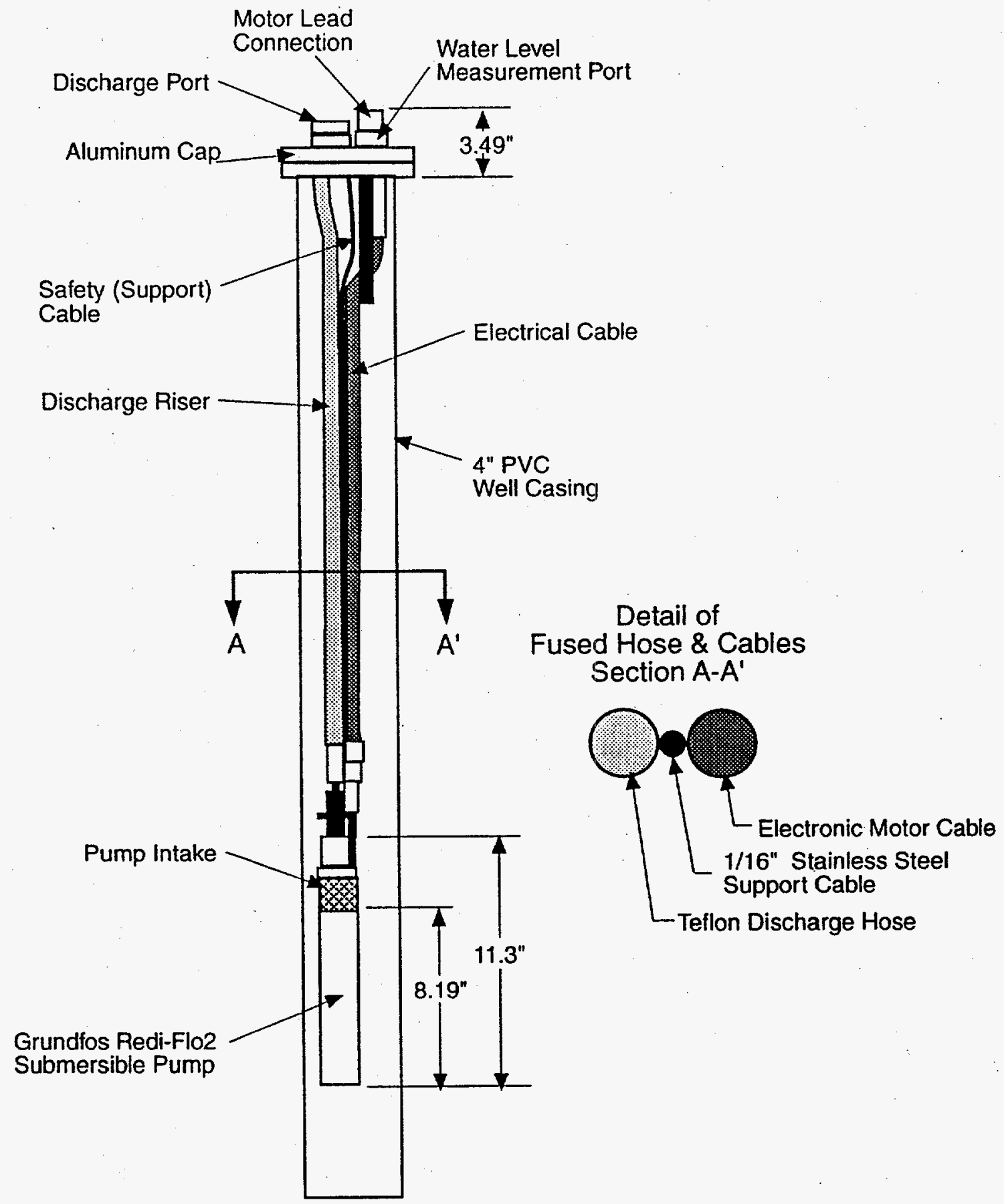

59402068.2

Figure 4.1. Purging and Sampling System 
seal/discharge/access system, called Dedicator, shown in Figure 4.1 and in detail in Figure 4.2. The enhancements in June 1992 were to address issues expressed by staff of Dames and Moore, the site assessment subcontractor. Staff mentioned the Grundfos pumps should be removed and examined to determine if biofouling or other deterioration of the pumps was present. They also suggested replacing one of the pumps in the UCD-22 monitoring well that had shown a steady deterioration in performance. The representative also noticed the surface discharge risers needed replacement because they were breaking and leaking as a result of coiling them inside the steel housing. The scope of work included:

1. Remove and examine the existing pumps, hoses, and seals on August 19 and 20, 1992, at the LEHR facility, University of Califomia, Davis, California.

2. Install a replacement pump for the pump that had shown declining performance in well UCD- 22 .

3. Replace the existing seals, hoses, and cables on 10 wells (UCD-15 through UCD-24) on August 19 and 20, 1992. Retrofit existing pumps with new assemblies of surface seal, motor lead, support cable, discharge hose (Teflon-lined polyethylene), and surface discharge riser. The discharge hose attached to the bottom of the seal had a single-fused cable and hose line that contained the $1.27-\mathrm{cm}(0.5-\mathrm{in}$.) diameter discharge hose, a stainless steel support cable [180-kg (400-lb) test], and the motor lead (an electrical cable supplying power to the pump). (Actual replacement took place on August 31 and September 1 and 2, 1992.)

The Dedicator surface seal has a multiple access port system with the following features: a leakproof up to 13,790 pascals (Pa) (2 psi) seal on the PVC well casing, which serves as a surface seal; a capped leakproof access port for water-level measurements or other sensors; the 1.8-m (6-ft) long discharge riser hose extensions used during purging and sampling and the storage port for them; and attachment of the fused motor lead, discharge riser, and stainless steel support cable to the pumps and surface seal.

The Dedicator has several advantages that include: 1) no leakage from the ground surface into below-ground completions past the waterproof seal, 2) the surface discharge hoses are quick connects and can be stored in the well casing when not in use, 3) all access ports are secured by cables or chains so they cannot accidentally fall into crevices or recesses of the outer housing and get lost or contaminated, 4) all wells are labeled with their proper well number so that surface seals can be easily identified during service or removal activities, and 5) the continuously sealed surface of the hose results in less contamination.

The first system of tubing and electrical cable was replaced with a product called Happy Hose. Happy Hose is a Teflon-lined polyethylene discharge riser hose that is fused with a supporting stainless steel cable, in addition to a shielded and sealed electrical cable. The advantages of the Happy Hose over the previous system that make it faster, cheaper, and safer include: 1) quick and easy 


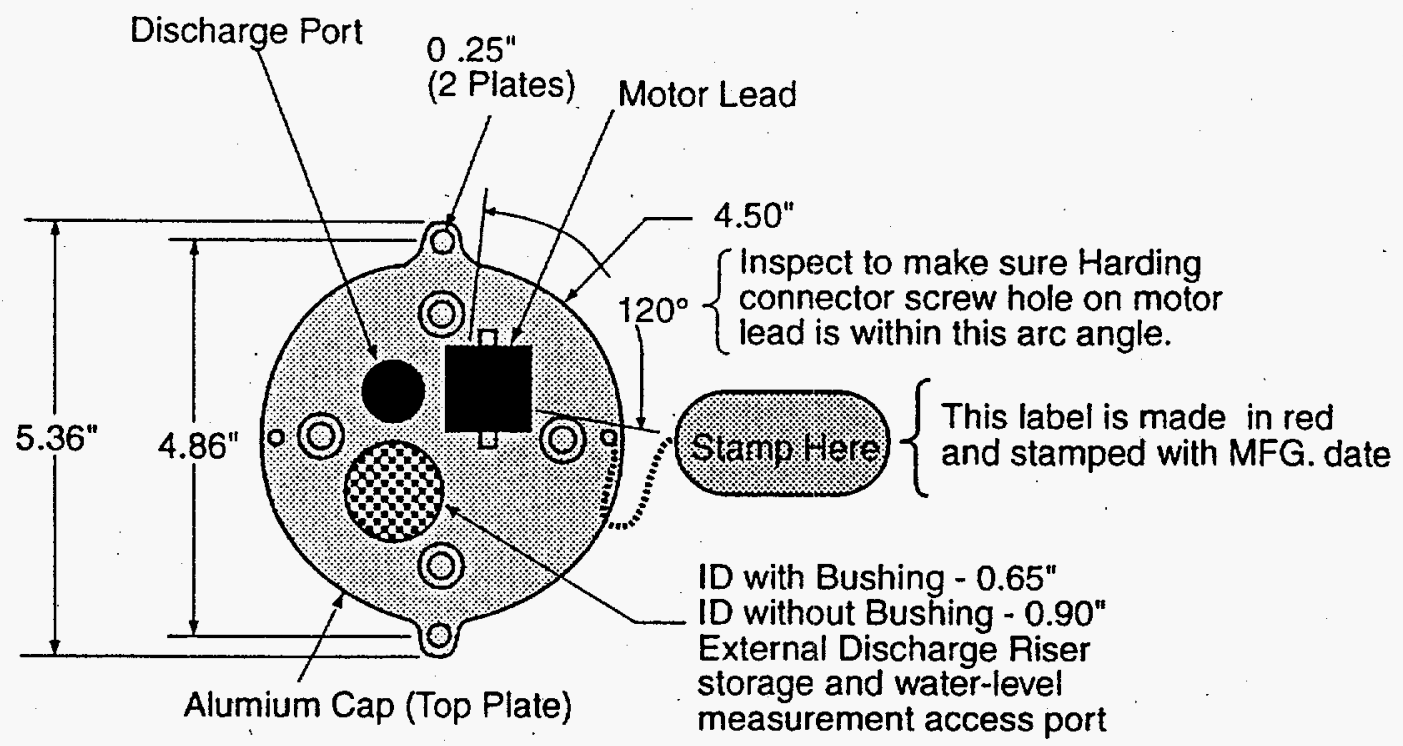

Motor Lead Connection with
Protective Cap in Place

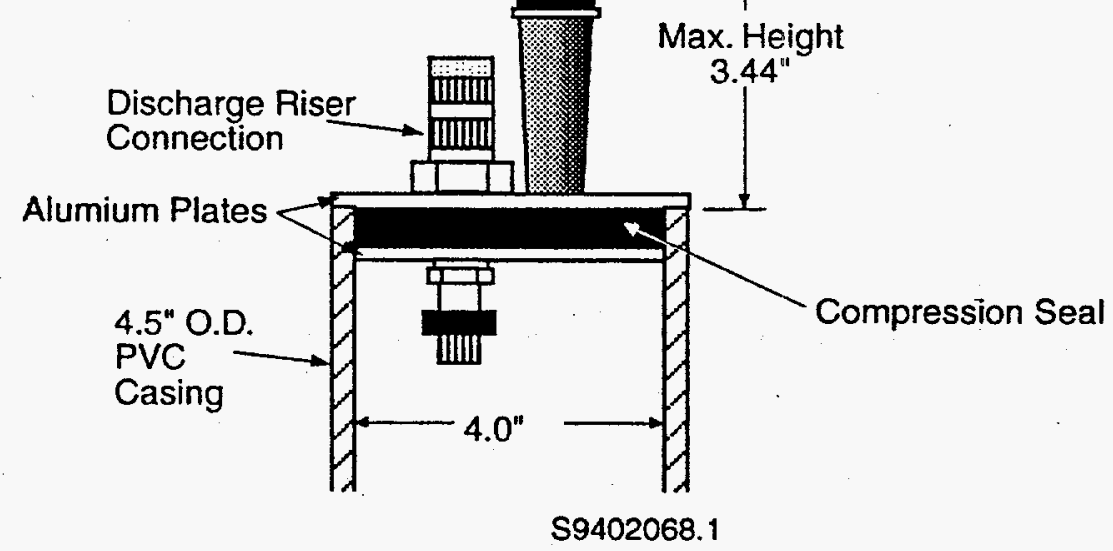

Figure 4.2. Details of Dedicator System

installation, decontamination, and removal because no kinking or tangling of the three lines occurs during installation and no place is found to trap contamination, 2) safer because it is nearly impossible for entanglement with the cables or tapes of water-level measurement devices or chemical sensors during their insertion and withdrawal, 3) safer and cheaper because the security cable built into the electrical cable reduces the chance of the pump pulling loose and falling to the bottom of the well or 
of the hose or electrical connections being pulled apart during installation and removal of the pump or other systems in the well. Previously, no steel support cables were used for supporting installed equipment, such as sampling pumps, in any of the wells at LEHR.

To ensure representative sampling by selecting optimal placement of the pump depth, the following factors were considered: the seasonal changes in water levels, the hydrostratigraphy based on well logs, and the stagnant water intervals present in all wells. By considering these factors, the amount of purge water could be reduced to obtain a representative sample. The following lengths from the top of the PVC casing to the bottom of the Redi-Flo2 pumps were used:

UCD-15: $27.9 \mathrm{~m}(92 \mathrm{ft})$
UCD-16: $28.2 \mathrm{~m}(93 \mathrm{ft})$
UCD-17: $27.3 \mathrm{~m}(90 \mathrm{ft})$
UCD-18: $20.3 \mathrm{~m}(67 \mathrm{ft})$
UCD-19: $21.8 \mathrm{~m}(72 \mathrm{ft})$
UCD-20: $21.2 \mathrm{~m}(70 \mathrm{ft})$

UCD-21: $21.2 \mathrm{~m}(70 \mathrm{ft})$

UCD-22: $21.2 \mathrm{~m}(70 \mathrm{ft})$

UCD-23: $21.2 \mathrm{~m}(70 \mathrm{ft})$

UCD-24: $21.2 \mathrm{~m}(70 \mathrm{ft})$

The resulting depths of installation and location of pump intake in relation to screened interval and lowest water levels are shown in Table 4.1. Recommendations were made to the manufacturer

Table 4.1. Well Construction Information and Pump Depths at LEHR (August 1992)

\begin{tabular}{|c|c|c|c|c|c|c|}
\hline $\begin{array}{l}\text { Well } \\
\text { Name }\end{array}$ & $\begin{array}{l}\text { Screened } \\
\text { Interval } \\
\text { BGS (ft) }\end{array}$ & $\begin{array}{l}\text { PVC Casing } \\
\text { Above (+) or } \\
\text { BGS (-) (ft) }\end{array}$ & $\begin{array}{l}\text { Height of } \\
\text { Top of } \\
\text { PVC Pipe } \\
\text { Elevation } \\
\text { (ft) }\end{array}$ & $\begin{array}{c}\text { Lowest } \\
\text { Water } \\
\text { Level Depth } \\
\text { BGS (ft) }\end{array}$ & $\begin{array}{l}\text { Pump Intake } \\
\text { Depth Below } \\
\text { Top of PVC } \\
\text { (ft)(a) }\end{array}$ & $\begin{array}{l}\text { Pump Intake } \\
\text { Depth Below } \\
\text { BGS (ft)(a) }\end{array}$ \\
\hline UCD-15 & $116.0-91.0$ & +1.6 & 50.94 & 70.94 & 91.3 & 89.7 \\
\hline UCD-16 & $116.5-91.5$ & +1.0 & 49.18 & 69.18 & 92.3 & 91.3 \\
\hline UCD-17 & $113.0-88.0$ & +1.7 & 51.48 & 70.48 & 89.3 & 87.6 \\
\hline UCD-18 & $70.9-55.9$ & +0.9 & 47.75 & 64.75 & 66.3 & 65.4 \\
\hline UCD-19 & $72.5-57.5$ & +1.2 & 50.49 & 70.49 & 71.3 & 70.1 \\
\hline UCD-20 & $72.5-57.5$ & +1.0 & 48.94 & 68.94 & 69.3 & 68.3 \\
\hline UCD-21 & $74.5-59.5$ & -0.7 & 48.00 & 67.00 & 69.3 & 70.0 \\
\hline UCD-22 & $72.0-57.0$ & -0.6 & 48.36 & 68.36 & 69.3 & 69.9 \\
\hline UCD-23 & $71.5-56.5$ & -0.6 & 48.57 & 67.57 & 69.3 & 69.9 \\
\hline UCD-24 & $72.0-57.0$ & -0.6 & 48.16 & 68.16 & 69.3 & 69.9 \\
\hline
\end{tabular}

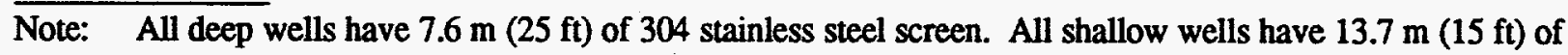
304 stainless steel screen.

BGS $=$ Below Ground Surface.

(a) Bottom of pump is approximately $0.21 \mathrm{~m}(0.7 \mathrm{ft})$ below the pump intake. 
(Instrumentation Northwest, Inc.) to improve the Dedicator. These recommendations were incorporated into the next version of Dedicator systems installed at LEHR. Manufacturers of the system were informed of the following PNL recommendations:

- The tops of PVC casing must be cut level.

- The inside diameter of water level measurement access port should be enlarged.

- The bushing should allow for storage of the discharge hose in a separate port.

- All fittings and connectors should have coarser threads with fewer threads per inch for easier, quicker connections and to eliminate cross threading.

- Dedicator should not slip over but slip inside and rest on the top edge of the PVC for minimal clearance and to eliminate problems of sealing.

- If male-threaded end was on the PVC casing, a compression system was used to provide a 34,475- $\mathrm{Pa}$ (5-psi) seal, or a sliced thread to release built up pressure in the well during removal of the access port caps.

- The system should be factory built or retrofitted. Retrofitting of the new hose in the field and dedicator system took nearly 40 min for each of the 9 wells. (In contrast, the installation of the factory-assembled unit in well UCD-22 took about $1 \mathrm{~min}$ to install.) 


\subsection{Cost Evaluations}

Monitoring well costs are exclusively capital costs, but cost savings occur during development and the operational phase of the pump portion of the system. Even though capital costs were not an issue at the time of initial installation of the pumps and accessories (discharge hoses, electrical and support cables), because they were provided free-of-charge for demonstration purposes, some capital costs of the sampling pumps and the retrofitted sampling pumps are discussed, in addition to the operational costs of the system.

\subsection{Monitoring Well Costs}

The 10 new monitoring wells were constructed with stainless steel wire-wrap well screen to expedite development, minimize turbidity, and maximize the percentage of open area in the screened interval. The cost of stainless steel for three deep and seven shallow wells is shown in Table 5.1. The total additional cost of the stainless steel casing, above PVC slotted casing was $\$ 6462$. Most of this cost was justified by reduced development time, and by long-term reduction of turbidity to meet more stringent regulatory requirements for groundwater samples. Additional advantages of stainless steel over both types of PVC screens include superior strength, and negligible risk of damage during

Table 5.1. Cost Comparison of Screen Altematives in 10-Cm (4-In.) Diameter Wells

Unit Description and Dimension

Cost per Foot

Cost per Deep

Well for $25 \mathrm{ft}$

Cost per Shallow

Well for $15 \mathrm{ft}$

Cost of 3

Deep Wells

Cost of 7

Shallow Wells

Total Cost of

10 Screens

Additional Cost

Above PVC

Slotted Casing

\section{Stainless Steel}

Wire-Wrap Screen (\$)

41.70

1042.50

625.50

3127.50

4378.50

7506.00

6462.00
PVC Wire-Wrap

Well Screen $(\$)$

18.30

457.50

274.50

1372.50

1921.50

3294.00

2250.00
PVC Slotted

Casing (\$)

5.80

145.00

87.00

435.00

609.00

1044.00

None 
installation and development because of high collapse and column strength of the stainless steel screen. Relative to the cost of construction and development of the 10 wells, the additional cost of the stainless steel wire-wrap well screen represents less than 3 percent of additional cost to well construction. Reduction of well development time at $\$ 150$ per hour for 40 hours per 10 wells may account for most of the $\$ 6462$, but operational cost savings resulting from lower turbidity samples are difficult to assess.

\subsection{Costs of Pump and Accessories}

A total of 10 new Redi-Flo2 purge and sample pumps, manufactured by Grundfos, with 30.3-m $(100$-ft) motor leads and $1.27-\mathrm{cm}(0.5$-in.) risers, were installed in the new monitoring wells at LEHR. This pump model represents new technology for purging and sampling monitoring wells. The pump [about $33 \mathrm{~cm}$ (13 in.) long] and its associated components are constructed of materials recommended for sampling hazardous waste compounds from monitoring wells. The pump has a single-phase, converter $230 \mathrm{~V}$ input and varies the voltage frequency from 46 to 400 hertz. Thus, a variable speed and variable performance range of $26.5 \mathrm{~L}$ per $\min (7 \mathrm{gpm})$ during well purging to $100 \mathrm{ml}(3 \mathrm{fl} \mathrm{oz})$ per minute during sampling are possible. Discharge rates may be easily varied by adjusting a single control dial. The $4.62-\mathrm{cm}(1.82-\mathrm{in}$.) outside diameter of the pump allows generous clearances for water-level measurement devices and instrumentation. This improvement has not been possible with other commercial submersible pumps in 10.2-cm (4-in.) diameter monitoring wells. Only one other sampling pump on the market, the Hydrostar ${ }^{\mathrm{TM}}$, has the performance range needed at LEHR for both sampling and purging. As shown in Table 5.2, the Hydrostar is more costly to install than the Grundfos Redi-Flo2.

Table 5.2. Comparison of Three Variable Discharge Pumps

\begin{tabular}{lcccc}
\multicolumn{1}{c}{ Parameter } & $\begin{array}{c}\text { Original } \\
\text { Bladder Pump }\end{array}$ & $\begin{array}{c}\text { Hydrostar } \\
\text { Piston Pump }\end{array}$ & $\begin{array}{c}\text { Redi-Flo2 } \\
\text { Submersible Pump }\end{array}$ \\
\cline { 4 - 5 } Installation Cost per Well & & 650 & $\$ 1320$ & $\$ 900$ \\
Total Installation Cost & $\$ 6500$ & $\$ 13,200$ & $\$ 9000$ \\
Purge Rate (L/min) & 3.79 & 17.8 & 26.5 \\
Sampling Rate (ml/min) & 100 & 100 & 100 \\
Field Sampling Efficiency & Fair & Fair & Fair & Good \\
Ease of Operation & Good & Good & Good \\
Reliability & Good & Good & Good \\
Suitability for Sampling VOC & Good & Poor & Good \\
Ease of Installation & & & Good
\end{tabular}

Note: Total cost is based on 10 wells, not including costs of controllers and surface seals (Dedicators). 
Bladder pumps are the most commonly used purge and sampling pumps in the industry and for most installations typically cost 20 to 25 percent less (approximately $\$ 250$ each at LEHR) than the Redi-Flo2, but lack the advantages for labor saving during purging because bladder pumps of comparable size only purge at a maximum of about $3.79 \mathrm{~L} / \mathrm{min}(1.0 \mathrm{gpm})$ for conditions at the UC Davis project. Approximately 284 to $758 \mathrm{~L}$ (75 to $200 \mathrm{gal}$ ) of water are purged from each 10.2-cm (4-in.) diameter monitoring well prior to slowing the discharge rate for sampling. At a $3.79 \mathrm{~L} / \mathrm{min}(1.0 \mathrm{gpm})$ purge rate with a bladder pump, purging $284 \mathrm{~L}$ ( 75 gal) would take approximately $75 \mathrm{~min}$, but RediFlo2 purging at $26.5 \mathrm{~L} / \mathrm{min}(7 \mathrm{gpm})$ requires only $10 \mathrm{~min}$. The time saved per well is $65 \mathrm{~min}$ for each of the seven shallow wells. For the three deep wells, the savings is even greater because the volume of $758 \mathrm{~L}$ ( $200 \mathrm{gal}$ ) can be purged in $29 \mathrm{~min}$ or a savings of $171 \mathrm{~min}$, almost $3 \mathrm{hr}$. For the 10 wells at LEHR using these pumps, $16 \mathrm{hr}$ of labor are saved each quarterly sampling. The ease of use of this pump probably saves an additional $1 \mathrm{hr}$ or so of sampling time per quarter. However, that savings is not included in the calculations presented here because documentation consists of anecdotal information rather than observed results: At a fully burdened charge-out rate of $\$ 75 \mathrm{per} \mathbf{~ h r}$, this is a labor savings of $\$ 1200$ every quarter, or $\$ 4800$ annually. The additional cost of 10 Redi-Flo2 pumps is approximately $\$ 2500$, which is approximately equal to the savings achieved during the first two quarters of sampling. This 6-month time frame to amortize the costs is similar to, but shorter than, the 1- to 2-yr time frame at other sites (Parker et al. 1993). Cost of controllers and the surface seal (Dedicator) system was common to all pumping systems and was not added to their cost. The Dedicator surface well seal completion system is discussed in the following paragraphs.

The equipment known as the Dedicator consists of 10 surface well seals with quick connect multiport connections and access port, and an average $24.2-\mathrm{m}(80-\mathrm{ft})$ length of Happy Hose (a fused riser, support cable, and motor lead) for each of the 10 wells. These new systems cost $\$ 640$ for each well or a total of $\$ 6400$. The labor cost to install them is approximately $\$ 1600$. If all the wells had been factory-assembled, installation time would have been an average of $10 \mathrm{~min}$ for each of the 10 wells, not including driving time from well to well. Therefore, had they been assembled at the factory, the installation costs would have been reduced to about $\$ 200$. The total cost of adding these features was about $\$ 8000$. The quick connects on the Dedicator reduce setup and disconnect time while ensuring isolation from surface contaminants. The savings in operation costs per quarterly sampling is about $2 \mathrm{hr}$ for 10 wells. At a fully burdened charge-out rate of $\$ 75 \mathrm{per} \mathrm{hr}$, the savings equals the modest sum of $\$ 150$ per quarter or $\$ 600$ per yr. It would require $10 \mathrm{yr}$ of these cost savings to equal the additional cost of the Dedicator. However, other less easily quantifiable, but important, operational benefits are provided by ensuring sample integrity. The Dedicator ensures sample integrity because it eliminates entry of external contaminants and prevents surface spillage of contaminated water. It appears, based on repeated examination over 3 yr, the Happy Hose component will remain unfouled over years of use at LEHR. 


\subsection{Summary and Conclusions}

The monitoring well portion of the enhanced groundwater collection system provided substantial improvement in the reduction of turbidity over previous designs of wells at the site. Dedicated groundwater sampling pumps were installed at LEHR at UC Davis to achieve cost savings and improved quality of the samples. The accessory items, Dedicator and Happy Hose, were added to improve ease of use, to improve safety, to ensure sample integrity from external influences, and to avoid future difficulties associated with degradation of the systems or obstructions to water level measurement and other instrumentation. The cost savings from the new well design that ensure vertical hydraulic isolation and reduce water sample turbidity is difficult to assess; however, at a minimum, the additional material costs were offset by the reduced development time. The long-term net cost savings of the pump portion of the groundwater sample collection system began in the summer of 1992 , resulting in a net cost savings of at least $\$ 4800$ per year on these first 10 wells. Additional cost savings will be achieved as these pumps are added to other groundwater sampling wells on-site. Already the site uses 23 of these pumps. The monitoring well network is estimated to increase to 35 wells by 1995 for a total additional capital cost of $\$ 8250$. The annual cost savings will amount to $\$ 16,800$ or a net operational cost savings over 5 yr of $\$ 75,750$. Although quantifiable operational cost savings of the Dedicator and Happy Hose accessories contribute to the minor ease-ofuse cost savings, their value added also lies in safety, the potential reduction of biofouling, and the assurance that well integrity is not compromised by introduction of foreign substances. The net additional cost of about $\$ 3000$ can be considered money well-spent, if it prevents even one well from being contaminated with external fluids and particulates over the next $5 \mathrm{yr}$. 


\subsection{References}

American Society for Testing and Materials. 1990a. "D5092-90, Recommended Practice for Design and Installation of Groundwater Monitoring Wells in Aquifers," Annual Book of ASTM Standards, Vol. 04.08. Philadelphia, Pennsylvania.

American Society for Testing and Materials. 1990b. "F480-90, Specifications for Thermoplastic Well Casing Pipe and Couplings Made in Standard Dimension Ratios (SDR)." Annual Book of ASTM Standards, Vol. 08.04. Philadelphia, Pennsylvania.

Anderson, K. E. 1977. Water Well Handbook. pp. 281. Missouri Water Well \& Pump Contractors Association., Inc., Rolla, Missouri.

Barcelona, M. J., J. P. Gib, and R. A. Miller. 1983. A Guide to the Selection of Materials for Monitoring Well Construction and Groundwater. p. 78. Contract Report 327, Illinois State Water Survey, Champaign, Illinois.

Barcelona, M. J., and J. A. Helfrich. 1986. "Well Construction and Purging Effects on Groundwater Samples." Environmental Science and Technology 20(11):1179-1184.

Barcelona, M. J., and J. A. Helfrich. 1992. "Realistic Expectations for Ground-Water Investigations in the 1990s." Current Practices in Groundwater and Vadose Zone Investigations. D. M. Nielsen and M. S. Sara, eds. pp. 3-23. American Society for Testing and Materials, Special Technical Publication 1118, Philadelphia, Pennsylvania.

Barcelona, M. J., J. A. Helfrich, and E. E. Garske. 1985. "Sample Tubing Effects of Groundwater Samples," Analytical Chemistry 5:460-464.

Barcelona, M. J., J. A. Helfrich, and E. E. Garske. 1988. "Verification of Sampling Methods and Selection of Materials for Ground-Water Contamination Studies." In Proceedings of the ASTM Symposium on Field Methods for Groundwater Contamination Studies. pp. 221-231. American Society for Testing and Materials, Special Technical Publication 963, Philadelphia, Pennsylvania.

Barcelona, M. J., J. A. Helfrich, E. Garske, and J. P. Gib. 1984. "A Laboratory Evaluation of Groundwater Sampling Mechanisms." Ground Water Monitoring Review 4(2):32-41.

Barcelona, M. J., H. A. Wehrman, and M. D. Varljen. 1994. "Reproducible Well-Purging Procedures and VOC Stabilization Criteria for Groundwater Sampling." Groundwater 32(1):12-22.

Bikis, E. A. 1979. “A Laboratory and Field Study of Fiberglass and Continuous-Slot Screens." Groundwater 17(1):111 (Abstract).

Chamness, M. A., S. P. Luttrell, D. J. Bates, and W. J. Martin. 1990. 2101-M Pond Hydrogeologic Characterization Report. PNL-7468, Pacific Northwest Laboratory, Richland, Washington.

Clark, L., and P. A. Turner. 1983. "Experiments to Assess the Hydraulic Efficiency of Well Screens." Groundwater 21(3):270-281.

Dunbar, D., H. Tuchfeld, R. Siegel, and R. Sterbentz. 1985. “Groundwater Quality Anomalies Encountered During Well Construction, Sampling and Analysis in the Environs of a Hazardous Waste Management Facility." Ground Water Monitoring Review 5(3):70-74.

Garske, E. E., and M. R. Schock. 1986. "An Inexpensive Flow-Through Cell And Measurement System For Monitoring Selected Chemical Parameters." Ground Water Monitoring Review 6(3):79-84. 
Gass, T. E., J. F. Barker, R. Dickhout, and J. S. Fyfe. 1991. "Test Results of the Grundfos Groundwater Sampling Pump." In Proceedings of the Fifth National Symposium on Aquifer Restoration and Groundwater Monitoring. National Water Well Association, Dublin, Ohio.

Gibs, J., G. A. Brown, K. S. Turner, C. L. MacLeod, J. C. Jelinski, and S. A. Koehnlein. 1993. "Effects of Small-Scale Vertical Variations in Well-Screen Inflow Rates and Concentrations of Organic Compounds on the Collection of Representative Ground-Water-Quality Samples." Groundwater 31(2):201-208.

Gibs, J., and T. E. Imbrigiotta. 1990. "Well-Purging Criteria for Sampling Purgeable Organic Compounds." Groundwater 28(1):68-78.

Gillespie, G. A. 1992. “An Effective Monitoring Screen for Fine Sand Aquifers.” Current Practices in Groundwater and Vadose Zone Investigations. D. M. Neilsen and M. N. Sara, eds. pp. 241-255. American Society for Testing and Materials, Special Technical Publication 1118, Philadelphia, Pennsylvania.

Gillham, R. W., and S. F. Ohannesin. 1990. "Sorption of Aromatic Hydrocarbons by Materials Used in Construction of Groundwater Sampling Wells." In Proceedings of the Standards Development for Groundwater and Vadose Zone Monitoring Investigations. D. M. Nielsen and A. I. Johnson, eds. pp. 108-122. American Society for Testing and Materials, Special Technical Publication 1053, Philadelphia, Pennsylvania.

Hall, S. H. 1993. "Single Well Tracer Tests In Aquifer Characterization." Groundwater Monitoring and Remediation 13(2):118-124.

Hall, S. H., S. P. Luttrell, and W. E. Cronin. 1991. "A Method For Estimating Effective Porosity And Ground-Water Velocity." Groundwater 29(2):171-174.

Hall, S. H., and J. R. Raymond. 1992. "Geohydrologic Characterization For Aquifer Thermal Energy Storage." In Proceedings of the 27th Intersociety Energy Conversion Engineering Conference, Vol. 4, pp. 101-107. Society of Automotive Engineers, Warrendale, Pennsylvania.

Herzog, B., J. Pennino, and G. Nielsen. 1991. “Groundwater Sampling." Chapter 11 in A Practical Handbook of Groundwater Monitoring. D. M. Nielsen, ed. p. 717. Lewis Publishers, Chelsea, Michigan.

Imbrigiotta, T. E., J. Gibs, T. V. Fusillo, G. R. Kish, and J. J. Hochreiter. 1988. "Field Evaluation of Seven Sampling Devices for Purgeable Organic Compounds in Groundwater." In Proceedings of the ASTM Symposium on Field Methods for Groundwater Contamination Studies. pp. 258-273.

American Society of Testing Materials, Special Technical Publication 963, Philadelphia, Pennsylvania.

Jackson, P. A. 1983. “A Laboratory and Field Study of Well Screen Performance and Design." Groundwater 12(6):771-772 (Abstract).

Kearl, P. M., N. E. Korte, and T. A. Cronk. 1992. "Suggested Modifications to Groundwater Sampling Procedures Based on Observations from the Colloidal Borescope." Ground Water Monitoring Review 12(2):155-161.

Kill, D. L. 1989. "Monitoring Well Development - Why and How." In Proceedings of the Standards Development for Groundwater and Vadose Zone Monitoring Investigations.

D. M. Neilsen, ed. American Society of Testing Materials, Special Technical Publication 1053, Philadelphia, Pennsylvania. 
Knobel L. L., and L. J. Mann. 1993. "Sampling for Purgeable Organic Compounds Using PositiveDisplacement Piston and Centrifugal Submersible Pumps A Comparative Study." Ground Water Monitoring and Remediation 13(2):142-148.

Liikala, T. L., D. S. Daly, and A. P. Toste. 1988, An Evaluation Of The Effects Of Well Construction Materials And Ground-Water Sampling Equipment On Concentrations Of Volatile Organic Compounds. PNL-6585, Pacific Northwest Laboratory, Richland, Washington.

Maltby, V., and J. P. Unwin. 1992. “A Field Investigation of Ground-Water Monitoring Well Purging Techniques." Current Practices in Groundwater and Vadose Zone Investigations. D. M. Neilsen and M. N. Sara, eds. pp. 281-299. American Society of Testing Materials, Special Technical Publication 1118, Philadelphia, Pennsylvania.

Martin-Hayden J. M., G. A. Robbins, and R. D. Bristol. 1991. "Mass Balance Evaluation of Monitoring Well Purging: Part II, Field Tests at a Gasoline Contamination Site." Journal of Contaminant Hydrology 8(1):225-241.

Miller, G. D. 1982. "Uptake and Release of Lead, Chromium and Trace Level Volatile Organics Exposed to Synthetic Well Casings." In Proceedings of the Second National Symposium on Aquifer Restoration and Groundwater Monitoring. pp. 236-245. National Water Well Association, Worthington, Ohio.

Muska, C. F., W. P. Colven, V. D. Jones, J. T. Scogin, B. B. Looney, and V. Price Jr. 1986, "Field Evaluation of Groundwater Sampling Devices for Volatile Organic Compounds." In Proceedings of the Sixth National Symposium and Exposition on Aquifer Restoration and Ground Water Monitoring Review. pp. 235-246. National Groundwater Well Association, Dublin, Ohio.

National Water Well Association. 1975. Manual of Water Well Construction Practices. EPA-570/9-75/991. Office of Water Supply, U.S. Environmental Protection Agency, Washington, D.C.

Nielsen, D. M., and G. L. Yeates. 1985. "A Comparison of Sampling Mechanisms for SmallDiameter Groundwater Monitoring Wells." Ground Water Monitoring Review 5(2):83-99.

Panko, A. W., and P. Barth. 1988. "Chemical Stability Prior to Ground-Water Sampling: A Review of Current Well Purging Methods." In Proceedings of the ASTM Symposium on Field Methods for Groundwater Contamination Studies. pp. 232-239. American Society of Testing Materials, Special Technical Publication 963, Philadelphia, Pennsylvania.

Parker, L. V. 1992. "Suggested Guidelines for the Use of PTFE, PVC, and Stainless Steel in Samplers and Well Casings." Current Practices in Groundwater and Vadose Zone Investigations, D. M. Neilsen and M. N. Sara, eds. pp. 217-229. American Society of Testing Materials, Special Technical Publication 1118, Philadelphia, Pennsylvania.

Parker, T. K., M. F. Eisen, A. A. Kopania, A. Robertson, R. L. Eades, and G. Thomas. 1993. "Selection, Design, Installation and Evaluation of Dedicated Groundwater Sampling Systems: A Case Study." In Proceeding of the National Groundwater Sampling Symposium, pp. 89-98. National Water Well Association, Dublin, Ohio.

Paul, D. G., C. D. Palmer, and D. S. Cherkauer. 1988. "The Effect of Construction, Installation, and Development on the Turbidity of Water in Monitoring Wells in Fine-Grained Glacial Till." Ground Water Monitoring Review 7(1):73-82.

Paul, C. J., and R. W. Puls. 1992. "Comparison of Ground-Water Sampling Devices Based on Equilibration of Water Quality Indicator Parameters." EPA-600/A-93/005. R. S. Kerr Environmental Research Laboratory, Ada, Oklahoma. 
Pearsall, K. A., and D. A. Eckhardt. 1987. "Effects of Selected Sampling Equipment and Procedures on the Concentration of Trichloroethylene and Related Compounds in Groundwater Samples." Ground Water Monitoring Review 7(2):64-73.

Pohlmann, K. F., and J. W. Hess. 1988. "Generalized Groundwater Sampling Device Matrix." Ground Water Monitoring Review 8(4):82-84.

Powell, R. M., and R. W. Puls. 1993. "Passive Sampling of Groundwater Monitoring Wells Without Purging: Multilevel Well Chemistry and Tracer Disappearance." Journal of Contaminant Hydrology 12:51-77.

Puls, R. W., and M. J. Barcelona. 1989a. "Filtration of Groundwater Samples for Metals Analysis." Hazardous Waste and Hazardous Materials 6(4):385-393.

Puls, R. W., and M. J. Barcelona. 1989b. "Groundwater Sampling for Metals Analyses." USEPA Superfund Groundwater Issue. EPA/540/4-89/001, Environmental Protection Agency, Washington, D.C.

Puls, R. W., D. A. Clark, B. Bledsoe, R. M. Powell, and C. J. Paul. 1992. "Metals in Groundwater: Sampling Artifacts and Reproducibility." Hazardous Waste and Hazardous Materials. R. S. Kerr Environmental Research Laboratory, Ada, Oklahoma.

Puls, R. W., and R. M. Powell. 1992. "Acquisition of Representative Groundwater Quality Samples for Metals." Ground Water Monitoring Review 12(3 ):167-176.

Raber, E., J. Garrison, and V. Oversby. 1983. "The Sorption of Selected Radionuclides on Various Metal and Polymeric Materials." Radioactive Waste Management and the Nuclear Fuel Cycle 4(1):41-52.

Reynolds, G. W., and R. W. Gillham. 1985. "Absorption of Halogenated Organic Compounds by Polymer Materials Commonly Used in Groundwater Monitoring." In Proceedings, Second Canadian/American Conference on Hydrogeology. pp. 125-132. National Water Well Association, Dublin, Ohio.

Rinaldo-Lee, M. B. 1983. "Small vs. Large-Diameter Monitoring Wells." Ground Water Monitoring Review 3(1):72-75.

Robbins, G. A., and J. M. Martin-Hayden. 1991. "Mass Balance Evaluation of Monitoring Well Purging: Part 1, Theoretical Models and Implications for Representative Sampling." Journal of Contaminant Hydrology 8(1):203-224.

Robin, M. J. L., and R. W. Gillham. 1987. "Field Evaluation of Well Purging Procedures." Ground Water Monitoring Review 7(4):85-93.

Schalla, R. 1986. "A Comparison of the Effects of Rotary Wash and Air Rotary Drilling Techniques on Pumping Test Results." In Proceedings of the Sixth National Symposium and Exposition on Aquifer Restoration and Groundwater Monitoring. pp. 7-26. National Water Well Association, Dublin, Ohio.

Schalla, R. 1991. "Design and Installation of Groundwater Monitoring Wells." Chapter 7 in A Practical Handbook of Groundwater Monitoring. D. M. Nielsen, ed. p. 717. Lewis Publishers, Chelsea, Michigan. 
Schalla, R. 1992. "Current Practices in Groundwater and Vadose Zone Investigations, Deployment and Purging for In Situ Sensors in Monitoring Wells." In Proceedings of the Current Practices in Ground Water and Vadose Zone Investigations. D. M. Nielsen and M. S. Sara, eds. pp. 300-310. American Society of Testing Materials, Special Technical Publication 1118, Philadelphia, Pennsylvania.

Schalla, R. 1993. "In Situ Chemical Sensors: How Practical are They for Monitoring Groundwater?" Ground Water Monitoring Review 12(4):5-6.

Schalla, R., and R. W. Landick. 1986. "A New Valved and Air-Vented Surge Plunger for Developing Small-Diameter Monitoring Wells." Ground Water Monitoring Review 6(2)81-86.

Schalla, R., R. W. Wallace, R. L. Aaberg, S. P. Airhart, D. J. Bates, J. V. M. Carlile, C. S. Cline, D. I. Dennison, M. D. Freshley, P. R. Heller, E. R. Jensen, K. B. Olsen, R. G. Parkhurst, J. T. Rieger, and E. J. Westergard. 1988a. Interim Characterization Report for the 300 Area Process Trenches. PNL-6716, Pacific Northwest Laboratory, Richland, Washington.

Schalla, R., D. A. Myers, M. Simmons, J. M. Thomas, and A. P. Toste. 1988b. "The Sensitivity of Four Monitoring Well Sampling Systems to Low Concentrations of Three Volatile Organics." Ground Water Monitoring Review 8(3):90-96.

Schalla, R., and W. H. Walters. 1989. "Rationale for the Design of Monitoring Well Screens and Filter Packs." In Proceedings of the Standards Development for Groundwater and Vadose Zone Monitoring Investigations. D. M. Neilsen, ed. pp. 64-75. American Society of Testing Materials, Special Technical Publication 1053, Philadelphia, Pennsylvania.

Sevee, J. E., and P. M. Maher. 1989. "Monitoring Well Rehabilitation Using the Surge Block Technique." In Proceedings of the Standards Development for Groundwater and Vadose Zone Monitoring Investigations. D. M. Neilsen, ed. pp. 91-97. American Society of Testing Materials, Special Technical Publication 1053, Philadelphia, Pennsylvania.

Smith, R. M. 1988. Resource Conservation and Recovery Act Ground-Water Monitoring Projects for Hanford Facilities: Progress Report for the Period April 1 to June 31, 1988. PNL-6675, Pacific Northwest Laboratory, Richland, Washington.

Smith, R. M., D. J. Bates, and R. E. Lundgren. 1989. Resource Conservation and Recovery Act Ground-Water Monitoring Projects for Hanford Facilities: Progress Report for the Period January 1 to March 31, 1989. PNL-6957, Pacific Northwest Laboratory, Richland, Washington.

Stolzenburg, T. R., and D. G. Nichols. 1985. Preliminary Results On Chemical Changes In Groundwater Samples Due To Sampling Devices. EPRI EA-4118, Electric Power Research Institute, Palo Alto, Califormia.

Unwin, J. P. 1984, "A Laboratory Study of Four Methods of Sampling Groundwater for Volatile Organic Compounds." NCASI Technical Bulletin, No. 441. National Council of the Paper Industry for Air and Stream Improvement, New York.

Unwin, J. P., and V. Maltby. 1988. "Investigations of Techniques for Purging Ground-Water Monitoring Wells and Sampling Groundwater For Volatile Organic Compounds." In Proceedings of the ASTM Symposium on Field Methods for Groundwater Contamination Studies. pp. 240-252. American Society of Testing Materials, Special Technical Publication 963, Philadelphia, Pennsylvania.

U.S. Environmental Protection Agency (EPA). 1986. Resource Conservation and Recovery Act (RCRA) Groundwater Monitoring Technical Enforcement Guidance Document. Washington, D.C.

Williams, E. B. 1981. "Fundamental Concepts of Well Design." Groundwater 19(5):527-542. 
Winegardner, D. L. 1990. "Monitoring Wells: Maintenance, Rehabilitation, and Abandonment." In Proceedings of the Standards Development for Groundwater and Vadose Zone Monitoring Investigations. D. M. Neilsen, pp. 64-75. American Society of Testing Materials, Special Technical Publication 1053, Philadelphia, Pennsylvania.

Yeskis, D., S. Chiu, S. Meyers, I. Weiss, and T. Bloom. 1988. "Field Study of Various Sampling Devices and Their Effects on Volatile Organic Contaminants." In Proceedings of the Second National Outdoor Action Conference on Aquifer Restoration, Ground Water, Monitoring and Geophysical Methods, pp. 471-479. National Water Well Association, Dublin, Ohio.

Yu, J. K. 1989. “Should We Use a Well Foot (Sediment Trap) in Monitoring Wells?” Ground Water Monitoring Review 9(2):59-61. 


\section{Distribution}

No. of

Copies

Offsite

12 DOE/Office of Scientific and Technical Information

\section{Onsite}

4 DOE/Richland Operations Office

G. M. Bell

R. D. Hildebrand

R. G. Holt

M. W. Tiernan

2 Bechtel Hanford, Inc.

B. H. Ford

Public Reading Room

IT Hanford

W. S. Thompson

44 Pacific Northwest Laboratory

S. A. Attiga (10)

R. W. Bryce
No. of

Copies

M. A. Chamness

J. C. Evans

K6-84

K6-96

K $7-10$

K6-96

K6-84

K6-96

B1-40

K6-84

K6-84

K6-96

B $1-40$

K6-96

K6-96

K6-96

K6-96

K6-84

F. A. Spane

S. S. Teel

Publishing Coordination

Technical Report Files (5)

Routing

N3-05

B 1-40

K6-96
R. M. Ecker

M. J. Graham

P. M. Irving

S. A. Rawson

P. C. Hays (last)
SE-UI

K6-78

K6-98

K6-04

K6-86 